NBER WORKING PAPER SERIES

\title{
TWO DECADES OF JAPANESE MONETARY POLICY AND THE DEFLATION PROBLEM
}

\author{
Takatoshi Ito \\ Frederic S. Mishkin \\ Working Paper 10878 \\ http://www.nber.org/papers/w10878
}

\author{
NATIONAL BUREAU OF ECONOMIC RESEARCH \\ 1050 Massachusetts Avenue \\ Cambridge, MA 02138 \\ October 2004
}

This paper is written for the NBER 15th East Asian Seminar on Economics, June 25-27, 2004. The authors are grateful to Takeshi Kudo and Emilia Simeonova for their excellent research assistance. We also thank our discussants Ken Kuttner, and Kazuo Ueda, Kunio Okina and participants at seminars at the Bank of Japan, and the East Asian Seminar on Economics. Any views expressed in this paper are the views of the authors only and not the University of Tokyo, Columbia University or the National Bureau of Economic Research. The views expressed herein are those of the author(s) and not necessarily those of the National Bureau of Economic Research.

(C) 2004 by Takatoshi Ito and Frederic S. Mishkin. All rights reserved. Short sections of text, not to exceed two paragraphs, may be quoted without explicit permission provided that full credit, including @ notice, is given to the source. 
Two Decades of Japanese Monetary Policy and the Deflation Problem

Takatoshi Ito and Frederic S. Mishkin

NBER Working Paper No. 10878

October 2004

JEL No. E42, E52, E58

\section{ABSTRACT}

This paper reviews Japanese monetary policy over the last two decades with an emphasis on the experience of deflation from the mid-1990s. The paper is quite critical of the conduct of monetary policy, particularly from 1998 to 2003. The Bank of Japan's rhetoric was not helpful in fighting deflation, and the interest rate hike in August 2000 amid deflation was a serious mistake. Deflation can be quite costly, and a key element in both preventing and escaping deflation is the management of expectations, using either price level or inflation targeting, because the zero lower bound on interest rates means that the overnight interest rate can no longer be used as the instrument of monetary policy. This paper proposes how to best manage expectations to exit deflation. Price-level targeting overcomes theoretical problems, such as need for a history dependent strategy, associated with inflation targeting. However, because actions speak louder than words, management of expectations also involves non-conventional monetary policies, a combination of which might have to be tried to help the Japanese economy escape its deflationary trap.

Takatoshi Ito

Graduate School of Economics

University of Tokyo

7-3-1 Hongo, Bunkyo-ku, Tokyo 113-0033

JAPAN

and NBER

itointokyo@aol.com

Frederic S. Mishkin

Graduate School of Business

Uris Hall 619

Columbia University

New York, NY 10027

and NBER

fsm3@columbia.edu 


\section{Introduction}

The Japanese economy has been stagnant for more than ten years. The average growth rate from 1993 to 2003 is just above 1 percent. Since 1998, the inflation rate, either measured by GDP deflator or CPI, has been negative. The deflation has brought the CPI price level by the end of 2003 to $3 \%$ below the 1997 level. During the same period, the US CPI has increased by 12\%. Due to virtually zero growth and deflation, the Japanese nominal GDP had shrunk by 4\% from 1997 to 2002, while during the same period, nominal GDP of the United States has increased by $25 \%$.

Many problems have been pointed to as contributing factors that explain the "lost decade" in Japan. The burst bubble and the non-performing loans problem are often blamed for the poor performance of the early stage of the stagnation. By 2003, land and stock price indices have fallen to one-third to one-fourth of the respective peak in 1989-91. Slow policy responses to the non-performing loan problem resulted in the banking crisis of 1997-98 and the financial sector is still weak. The consumption tax rate increase and repeal of income tax cut in April 1997 is often regarded as a fiscal policy mistake. Slow structural reform in regulated sectors is another problem for the Japanese economy, which has not benefited from information and communication technology (ICT) advances that propelled the US economy.

But, the most likely cause for deflation in Japan is a failure of monetary policy, since inflation or deflation is ultimately a monetary phenomenon. The Bank of Japan was unable to stop the inflation rate from turning negative, despite its various efforts. The uncollateralized call rate (the policy interest rate that corresponds to the Federal Funds rate of the United States) was lowered to virtually zero in February-March 1999. The Bank of Japan raised the call rate to $0.25 \%$ in August 2000 in false expectation of continuing economic expansion, against protests from the government and many economists. The interest rate was lowered to zero again in March 2001, with an additional measure of quantitative easing, setting the target of current account (reserves) of commercial banks at the Bank of Japan in excess of required reserves. The target amount of current account was initially set at 5 trillion yen, while the required reserves was about 4 trillion yen. The target amount has been raised in several steps to a range of 30-35 trillion yen by January 2004. In addition to raising the target amount of current account at the Bank of Japan, the Bank expanded the amount of monthly outright purchase of long-term government bonds from 400 billion yen to 600 billion yen in August 2001, and in several steps to 1200 billion yen in October 2002. In addition, purchases of some of private debts, including asset-backed securities (ABS), have been introduced.

By 2002, the economy and the financial institutions weakened again. Deflationary expectations were setting in, and consumption and investment were depressed. Aggregate demand fell short of potential output, and the widened output gap depressed prices, reinforcing deflationary expectations. There did not seem to be a solution to the deflationary spiral. 
When the zero interest rate policy (ZIRP) was first introduced in February 1999, it was intended to continue until "deflationary concern is dispelled." It was then lifted in August 2000. When it was re-introduced in March 2001, it was declared to continue until "the inflation rate becomes stably above zero." The condition was further elaborated in October 2003, so that the necessary condition for the exit from ZIRP is that the CPI inflation rate becomes zero or above for a few months and there was no forecast by the Board members of falling back to deflation. The determination to fight deflation seems to have been strengthened. Given that deflation was not over at the time of ZIRP termination and that the ZIRP had to be re-instated, the interest rate hike of August 2000 was clearly a mistake.

Lively debates have taken place as to what the Bank of Japan could have done to prevent deflation from occurring and getting worse, and on what the Bank of Japan could do to get out of deflation. Many academics and policy makers, including studies at the Federal Reserve Board, argue that the Bank of Japan actions were too little too late, at least in retrospect, in preventing deflation from emerging and fighting out of deflation. Many academic critics have been arguing for non-conventional monetary policy in combating deflation: for example, purchasing long-term bonds, equities, foreign-currency-denominated bonds, and non-performing loans. However, it has been pointed out that the transmission channel of non-conventional monetary policy is unclear.

Inflation targeting has also been proposed as a tool to promote an independent central bank and to help get out of deflation. Namely, a credible announcement of inflation targeting, of say 1 to 3 percent, would make inflation expectations become higher, so that the deflationary spiral would be broken. A combination of inflation targeting as a communication and anchoring device with non-conventional policies was advocated by academic work in the past. ${ }^{1}$

However, the Bank of Japan has opposed inflation targeting, with economists in the Bank of Japan arguing that there are no clear instruments to get out of deflation, and a mere announcement without instruments would not convince market participants to change their inflation expectations. But, others in the Bank have suggested that the commitment to keep the zero interest rate policy until the inflation rate becomes stably above zero has similar effects to inflation targeting.

The paper is organized as follows. Sections 2 and 3 will review Japanese Monetary Policy over the last two decades. The former concentrates on the period of bubble and burst (1985-1997), and the latter examines the issue under the new law of the Bank of Japan (1998- ). Section 4 discusses whether estimates of Taylor rules can be used to assess Japanese monetary policy. Section 5 discusses the costs of deflation. Section 6 examines monetary policy actions to prevent deflation, and Section 7 surveys the literature on monetary policy to cure deflation and discusses non-conventional monetary policy measures. Section 8 concludes the paper.

1 See Ito $(2000,2001)$, Kazumasa Iwata $(2002)$, and Kikuo Iwata $(2001,2002)$ in the books written in Japanese. 


\section{Monetary Policy and the Bubble}

\subsection{Bubble and Burst}

Some researchers go back to the bubble period, 1985-90, as a source of the Japanese stagnation in the 1990s. Since the bubble occurred and burst, the Japanese economy fell into a difficult position of having nonperforming loans that led to the banking crisis. Some economists seem to believe that there was a mistake in monetary policy in the 1980s, and once the burst bubble occurred, monetary policy became powerless in the 1990s, because the transmission channel from the interest rate policy to the real economy was no longer operational. Therefore, it is entirely appropriate to start the story of deflation from the bubble years.

In retrospect, it is obvious that the Japanese economy was experiencing a bubble economy: The stock price index and the land price index quadrupled from 1983 to 1989. The stock prices index (Nikkei 225) rose from 10,000 yen at the end of 1983 to near 40,000 at the end of 1989. The economic growth rate was approaching 5\% surpassing the average of 4\% from 1975 to 1989 , and the tax revenues were increasing to close a fiscal gap that had plagued the economy for two decades. At the end of the 1980s, many economists as well as policy makers around the world were praising the

Japanese economy for its excellent performance. ${ }^{2}$ Although a few economists raised concerns, many financial analysts and bankers were not alarmed at the apparent high value of stocks and land compared to their cash-flow earning. Land and stock price movements from 1970 to 2003 are shown in Figure 1.

Insert Figure 1 about here

The inflation rate had gradually come down from 12 percent in 1974 to below 4 percent in 1978. The inflation rate suddenly went up to about 8 percent in 1979 due to the second oil crisis. However, the CPI inflation rate was quickly brought down to below 3 percent in 1982. The inflation rate fluctuated at the low range of 0-3\% for the rest of the 1980s. The inflation performance of Japan from 1976 to 1987, despite a lack of legal independence of the Bank of Japan, was often praised in the literature. ${ }^{3}$ Figure 2 shows the CPI inflation rate (excluding fresh food), that is adjusted for the consumption tax introduction in 1989, and the consumption tax rate increase in 1997.

Insert Figure 2 about here

It is remarkable that during the bubble period, the CPI inflation rate remained low. While asset prices were doubling and tripling in a few years, the CPI inflation rate remained quite reasonable, prompting

2 See Ito (1992) for comprehensive explanation of the Japanese economy up to 1991.

3 See, for example, Cargill, Hutchison, and Ito (1997), for the view that the Bank of Japan might have had de facto independence and exercised it wisely. 
a difficult choice to the Bank of Japan. Indeed, the Bank of Japan did not start tightening until 1989. Although the Bank of Japan would not target asset prices, the burst bubble would make monetary policy more difficult — all with the benefit of hindsight. The yen appreciated from 260 yen/dollar in February 1985 to 150 yen/dollar in the summer of 1986, of which some part was a movement toward an equilibrium and some part was overshooting. The sharp yen appreciation caused a recession (due to a slump of exports) and imported disinflation. Interest rates were lowered from 1996 to 1997 in part to help stimulate the economy that was depressed by sharp yen appreciation. ${ }^{4}$ Low interest rates were necessary to prevent the yen from appreciating too much.

Monetary policy was finally tightened in 1989. The official discount rate (ODR) rose from $2.5 \%$, where it had been since 1987 , to $3.25 \%$ in May 1989 . The ODR rose to $3.75 \%$ in October and $4.25 \%$ in December. Despite this rapid hike of the interest rate, the CPI inflation rate rose from $1 \%$ at the beginning of 1989 to $3 \%$ toward the end of the same year. The official discount rate was raised to 6.00\% in August 1990 (a 350 basis point hike in 15 months).

Stock prices peaked at the level of 39,000 in Nikkei 225 index at the end of 1989. In tandem with the interest rate hike, regulatory tightening was applied to stop increases in land prices: including limiting the increase in bank lending to real estate-related projects and companies in the spring of 1990, and raising taxes on realized capital gains from land investment. Stock prices finally turned down from the first trading day of 1990. The stock price index declined by one-third from the end of 1989 , the peak, to the end of 1990 . Stock prices continued to decline and the index lost $60 \%$ of the peak level by the summer of 1992. Land prices started to decline in 1991. The bubble had burst.

One may question whether monetary policy was too lax for too long during the bubble experience, that is the second half of the 1980s. What if monetary policy was tightened in 1988 ? Maybe that might have prevented the inflation rate from rising too quickly to the $3 \%$ level at the end of 1989. The Bank of Japan was most likely behind the curve. However, it probably would not have had a measurable impact on the bubble process of stock prices and land prices. Even if the interest rate had been hiked earlier, it is unlikely that the expected return of purchasing an asset would not have been affected very much when the asset is in a bubble process. ${ }^{5}$

Those who emphasize the damage of burst bubble in the 1990s may argue that the mistake of monetary policy in the second half of the 1980s was that it allowed the bubble to get bigger and bigger. There is no clear cut answer to the question of how monetary policy should respond to asset price

4 See, for example, Okina, Shirakawa, and Shiratsuka (2001) for such a view. They seem to blame international policy coordination, such as the Plaza Accord of September 1995 and the Louvre Accord of February 1997 for the Bank of Japan not acting in a timely manner.

5 See Ito and Iwaisako (1996) for an interpretation of the Japanese bubble in the 1980s as an application of stochastic bubbles. They differentiated the simulated effects of a temporary change in the interest rate and the simulated permanent change in the interest rate upon asset prices. They argue that unless the low interest rate in the late 1980s had been perceived to be permanent, the large increase in asset prices could not have been explained. 
inflation with a stable CPI inflation rate as will be seen in the general discussion in Section 2.3.

However, the dilemma of the monetary policy at the time was that CPI inflation was indicating low inflation, mainly due to a sharp yen appreciation, from 260 yen/dollar in February 1985 to 150 yen/dollar in the summer of 1986, and to 120 yen/dollar in December 1987. When the CPI inflation rate is about $0.5 \%$ while the stock and land prices are increasing at $30 \%$ annually, what should monetary policy do? The low inflation rate, which is below typical inflation targets of around $2 \%$, might suggest there is room for monetary easing, while stopping the asset price inflation requires tighter monetary policy. There seems to be dilemma for monetary policy.

There is a fundamental law in (linear model) economics that there should be at least two policy instruments to pursue two policy objectives. No perfect solution for the interest rate policy can be obtained to pursue both CPI price stability and asset price stability.

Assessment of monetary policy in Japan in 1987 and 1986 is difficult. Could one justify the monetary policy that lowered the discount rate to 2.5\% in February 1987 and maintained it at 2.5\%, then the record low, until May 1989? One may argue that the Bank of Japan should have applied tight monetary policy in 1987 in order to curb asset price inflation. But, it would have been difficult to justify the action given the low CPI inflation rate, the slow economic recovery from the yen-appreciation recession of 1986, and the aftermath of Black Monday in October 1987. We are not confident that preventing asset price inflation was an overriding priority of the central bank in 1987. On the other hand, the tradeoff had disappeared in 1988 when both CPI price forecasts and asset price movements now indicated that at least modest tightening would have been justifiable. The BOJ was probably behind the curve in 1988 .

\subsection{Bubble Overkill?}

In the beginning of the asset price decline, public opinion was favorable toward monetary and regulatory policy to stop the bubble. Housing was considered to have become too expensive to ordinary citizens, so stopping the housing price from skyrocketing was considered to be a good thing. Despite the burst of the bubble, robust consumption and investment continued in 1991. The GDP growth rate remained higher than 3\% in 1990 and 1991.

The Japanese economy slowed down considerably in 1992. Stock prices plummeted in the summer of 1992, to the level of 15,000 in Nikke 225 index, losing more than $60 \%$ of the peak value in two and half years. The quarter-to-quarter GDP growth rate became negative in the spring-summer of 1992. Lending to the real estate sector from banks slowed down after 1991 due to regulation, but there was a loophole. Lending via nonblank financial institutions (such as leasing companies) continued and total lending to the real estate, construction, and nonbank sectors remained high until the mid-1990s. Nonperforming loans, due to nonpayment of interest by real estate companies, 
became a popular topic of business discussion, but was not yet showing up in any banking statistics in the first half of the 1990s.

The discount rate was lowered to $5.5 \%$ in July 1991 , to $5 \%$ in November 1991, to $4.5 \%$ in December 1991. The decline of the official discount rate continued in 1992 and 1993. A fiscal stimulus package was introduced in 1992 in response to the weakening economy. This was the beginning of a series of fiscal stimulus packages.

The economy was stagnant from 1992 to 1994, with the growth rate below 1.2 percent, three years in a row. Land prices continued to decline steadily. The CPI inflation rate declined from just above 2 percent in the beginning of 1992 to 0 percent by mid-1995. Monetary policy was relaxed in 1992 and 1993 in response to weakening of the economy. The ODR was lowered from 4.5\% to 3.75\% in April 1992, to 3.25\% in July 1992, to 2.5\% in February 1993, and to 1.75\% in September 1993. There was no change in the ODR in 1994, but it was lowered to $1 \%$ in April 1995, and finally to $0.5 \%$ in September 1995.

The question from the viewpoint of preventing deflation is whether the pace of the interest rate cut from 1992 to 1995 was quick enough. The fact that the economy continued to be stagnant and the inflation rate dropped to $0 \%$ suggested that the Bank of Japan might have underestimated deflationary forces.

During the period 1992 to 1995, the nonperforming loans problem became worse and worse. Many construction and real estate companies were virtually bankrupt, since the market value of real estate in inventory had become much lower than their purchase values, and cash flows were dwindling. As a result, these companies were having trouble making interest payments on their bank loans. However, the banks, fearing that losses would become apparent and having a false belief the real estate market would rebound soon, kept lending to these companies that could not service their debt-a practice that became known as "ever-greening." The balance sheet of corporations and banks were quickly deteriorating.

Smaller financial institutions-housing loan companies, credit unions, one regional bank-failed in 1995. The banking problem was worsening, but no serious policy was introduced to address the problem. Since the seriousness was hidden behind murky accounting rules and a lenient bank supervisor (the Ministry of Finance), the public was not informed of the magnitude of the problem or a coming crisis. Since the public and politicians were not alarmed, there was little sympathy toward any suggestions for fiscal injections to recapitalize the banks.

Many economists called for introducing prompt corrective action for weak institutions and fiscal injection, if necessary, for either closing institutions or rehabilitating them. But, fiscal injection was politically difficult. Instead, in 1995, the Ministry of Finance, on the one hand guaranteed all deposits, suspending the deposit insurance ceiling, and on the other hand declared that no major bank would fail. 
In spite of a weak economy, the exchange rate was appreciating from 1993 to 1995 . The exchange rate appreciated from 100 yen/dollar to 80 yen/dollar in the spring of 1995, with no apparent macro-fundamental reasons for such a sudden move. The exchange rate appreciation dampened an expectation of early recovery and contributed to disinflation and then deflation.

The economy started to grow in the second half of 1995, and the year 1996 turned out to be a good one, with the growth rate exceeding $3 \%$. The yen depreciated to a level above 110 yen/dollar, providing additional support for a recovery. A fragile economic recovery of 1996 accelerated in the first quarter of 1997, as the pre-announced consumption tax rate increase of April 1997 induced consumers to accelerate big-ticket consumption. In April 1997, the consumption tax rate was raised from $3 \%$ to $5 \%$, and the temporary special income tax cut was allowed to expire, both as planned. The growth rate significantly slowed down in the second half of 1997. This was the result of the Asian currency crisis, and the banking crisis of the Japanese economy in November. The economy continued to deteriorate in 1998: the year 1998 recorded negative growth for the first time since 1976.

From 1997 to 1998, Japanese financial markets suffered from a severe crisis, as banks were losing capital due to high ratios of nonperforming loans and falling asset prices. Three large banks - Hokkaido Takushoku, Long-term Credit, and Nippon Credit—failed, and other banks were also suffering from declining capital. Banks were curtailing lending and a severe credit crunch was observed. The resulting negative effects on aggregate demand then pushed the economy into deflation.

The government finally decided to inject capital into the banks. The first capital injection in March 1998 turned out to be insufficient but the second capital injection of March 1999 finally calmed the market. Ito and Harada (2000) showed that the Japan premium - a risk premium demanded by western banks upon Japanese banks for interbank lending/borrowing — disappeared after March 1999.

\subsection{Asset Prices and monetary policy}

In retrospect of 1985-2003, there are several questions on what the Bank of Japan should or could have done. The first question is whether the Bank of Japan should have prevented the bubble. If all the trouble of the 1990s originates from the bubble, stronger actions should have been taken against the asset price increases. This question relates to a new debate over the objective of central banks. ${ }^{6}$ Some researchers, more than others, think that asset prices should be considered as a part of price stability that is the sole objective of many independent central banks. Cecchetti, et al (2000) argued strongly to put asset prices as direct measure of the goal of monetary policy.

6 A few conference volumes dedicated to this question have been published, see for example, Hunter, William C.; George G. Kaufman, and Michael Pomerleano, (2003) and Richards, Anthony and Tim Robinson (2003). 
Bernanke and Gertler (1999) examined monetary policy in the presence of asset price bubbles, with application to Japan. They built a model with an exogenous asset price bubble, and then apply alternative monetary policy rules. Then estimated reaction functions for the FED and BOJ. They applied the Clarida, Gali, and Gertler (1998) model to estimate reaction functions for the Federal Reserve and the Bank of Japan. The model assumes rational expectation for estimating expected inflation rate that is used to calculate the inflation rate gap. Their results indicate that the Japanese policy was too tight from 1985 to 1988 and too lax from 1988 to 1990, fueling a stock bubble, and too tight, again, from 1992 until at least 1996. They argue that even without explicitly targeting the asset prices, the Bank of Japan should have tightened from 1998 to 1990, probably ending the bubble, much earlier.

Okina and Shiratsuka (2002) criticized Bernanke and Gertler (1999) on the grounds that Berkanke and Gertler used a forward-looking inflation rate as expected inflation, but the inflation rate they used was not adjusted for consumption tax rate changes. Okina and Shiratsuka argued that the rapid increase of interest rate derived from the policy rule of Bernake and Gertler mainly resulted from the introduction of the consumption tax in April 1989. The paper by Okina, Shirakawa, and Shiratsuka (2001) contains a good review of why the bubble happened, how the BOJ reacted, and what could have been done, from the angle of the central bank. In section IV "Did the BOJ's Monetary Policy Create the Bubble?," the authors take the view that the BOJ lowered the interest rate from 1986 to 1987 to support the "policy coordination" framework, and to prevent the appreciation of the yen. Then paper then reviews the policy in 1988 and 1989.

There are many criticisms of the view that the central bank should pay special attention to asset prices beyond their effects on CPI. See, for example, Mishkin (2001) and Mishkin and White (2003). Ito (2003) emphasizes the role of bank supervision, rather than monetary policy, for preventing a bubble or managing a burst bubble.

The difficulty in using monetary policy (raising and lowering of the interest rate) alone to prevent a bubble can be summarized as follows. First, the central bank often would not know whether asset prices are rising due to fundamentals or due to a bubble. Second, when the bubble is in force, it would take very high interest rate to pop the bubble, and that would throw real variables into volatile fluctuations. Those skeptics emphasize the importance of supervision policy rather than monetary policy to maintain financial stability.

Given that a bubble is created, the effects from the bursting of the bubble could be moderated by monetary policy. The question is whether the Bank of Japan was behind the curve from 1992 to 1995 . The Bank of Japan may have been to slow to ease, possibly for fear of rekindling a bubble. Similarly, the Bank may have waited too long to adopt the ZIRP, possibly because it was an unprecedented move. Would policy have been better if the Bank adopted the ZIRP earlier than February 1999? 


\section{New Bank of Japan}

\subsection{Monetary policy of the Hayami regime, 1998-2003}

When the newly independent Bank of Japan started in April 1998, hopes were high in that the Bank of Japan would improve its performance and return to what had been viewed as successful monetary policy in the preceding two decades. However, after five years under the Hayami regime, the Bank of Japan has lost credibility and suffered a serious confidence problem. What happened? The short answers to these questions are two-fold. First, the Policy Board members, led by Governor Hayami, misjudged the economic conditions, maybe because they were too eager to go back to the "normal" situation where the interest rate is positive. The interest rate hike in August 2000 was a clear mistake of this kind. Second, the Governor and fellow Board members took independence literally and refused to cooperate with the Government when the economic conditions called for such cooperation. Since independence and early establishment of credibility were considered so important, policy actions became conservative, timid, and tentative. Cargill, Hutchison, and Ito (2000: p. 173) called this the "independence trap." Even when policy was finally directed toward quantitative easing in March 2001, this policy was not explained adequately, especially because the Bank of Japan had claimed that it was likely to be ineffective. Therefore the general public viewed the Bank of Japan as adopting a policy that the Bank did not believe in. That was hardly a good way of communicating with the market.

The old Bank of Japan, under the 1942 Law, was supposed to pursue monetary policy in order to maximize economic potential (not price stability), and the Governor could be replaced by the Minister of Finance, if the Governor did not follow the government instructions. ${ }^{7}$ A lack of independence is often cited as a cause for an unusually high inflation rate, about 30\%, in 1973-74, in the wake of the first oil crisis. After the inflation of 1973-74, the Bank of Japan had conducted prudent monetary policy, achieving a gradual decline in the inflation rate. Cargill, Hutchison, and Ito (1997; Chapter 8) have praised the conduct of the Bank of Japan, achieving a de facto independence based on reputation. Japan was known to have been an "outlier" in the relationship between the legal independence index and the historical inflation rate.

The new law, the Bank of Japan Law of 1998, guaranteed the independence of the Bank of Japan in its policy making and Board member appointments. ${ }^{8}$ The law became effective on April 1 ,

7 The 1942 Law specified that the Bank of Japan conducts its operation "in order that the general economic activities of the nation might adequately be enhanced" (Article 1). The objective of the Bank of Japan was "for achievement of national aims" (Article 2). These wordings should be understood in the context of the war when the bill was passed. See Cargill, Hutchison, and Ito (2000: chapter 4) for detailed comparison of the old and new Bank of Japan Laws.

8 The 1998 Law specifies two pillars, "the pursuit of price stability, contributing to the sound development of the national economy (Article 2)," and "maintenance of an orderly financial system (Article 1)." The absence of mentioning full employment, economic growth, or exchange rate objectives suggests that price stability is the primary objective. Financial system stability is a shared responsibility with government. 
1998. At around the same time, Mr. Hayami was appointed as Governor, and Mr. Yamaguchi and Mr. Fujiwara two deputy governors. Two policy board members were carried over from the old law regime, but four new members were appointed in April 1998 to replace the old members and vacancy. Mr. Hayami, age 72 at the time of new Governor appointment, left the Bank of Japan, after serving for 34 years on the international side of the Bank, in 1981 (17 years earlier) to go to a general trading company, Nissho-Iwai. After serving as President and Chairman of Nissho-Iwai, he had retired from the company for several years, until he returned to the Bank of Japan as Governor. Deputy Governor Yamaguchi had climbed up the ladder in the Bank of Japan, with a reputation for his knowledge about the core business of central banking. Deputy Governor Fujiwara was former journalist. Governor Hayami was brought back to the top position, partly because he was considered to be incorruptible in the wake of a scandal at the Bank of Japan. ${ }^{9}$

The Japanese economy in the spring of 1998 was in the process of falling into a serious recession and financial instability. In November 1997, financial instability became prominent: one large bank and one small bank, a large securities firm, and a medium-size securities firm all failed, and credit lines among the Japanese financial institutions, and between western financial institutions and Japanese financial institutions became severely limited. The Asian financial crisis was spreading from Thailand to Indonesia, to Korea, and to the region in general. Demand was falling and it was clear that the economy was heading into a recession. ${ }^{10}$ The overnight call rate, the market rate corresponding to the Federal Funds rate in the United States, at the time was about $0.4-0.5 \%$. This stance was maintained until September 9, 1998, when the target of the call rate was reduced to $0.25 \% .^{11}$

Another major step was taken in February 12, 1999. The Board decided to lower the overnight call rate as low as possible, with an immediate action to lower it to $0.15 \%$. $^{12}$ This is the

9 Many Bank officials were implicated for inappropriate behavior of dining and golfing with private-sector people. The scandal hit the media particularly hard in the first three months of 1997. High salaries, high severance pay and large company housing were also became a target of criticism. One Bank official was arrested for taking bribes in return for leaking information to a securities firm. Governor Matsushita and, Deputy Governor Fukui (who returned as Governor five years later) resigned to take responsibility in March 1998, days before the new BOJ law took effect. The official who took bribes was dismissed from the Bank on April 3, 1998.

10 In the spring of 1998, it was announced that the economy had just experienced the two-consecutive quarters of negative growth rates: $-0.7 \%$ in 1997:IV and -0.3\% in 1998:I. The currently available new SNA93 (System of National Accounts, following a United Nations recommendation of 1993) (http://www.esri.cao.go.jp/jp/sna/qe034-2/gdemenuja.html) does not show this: $+0.7 \%$ in 1997:IV and $-1.0 \%$ in 1998:I. The difference is due to the differences in the base year, the estimation methods, and the seasonal adjustment method. The point is that the Bank of Japan and the government should have had a more negative assessment of the economy at the time of Spring 1998.

11 "The Policy Board determined to further ease the stance of money market operations for the inter-meeting period ahead as follows: The Bank of Japan will encourage the uncollateralized overnight call rate to move on average around 0.25\%. (Bank of Japan, Announcement of Decisions, September 9, 1998) 12 "The Bank of Japan will provide more ample funds and encourage the uncollateralized overnight call rate to move as low as possible. To avoid excessive volatility in the short-term financial markets, the Bank 
beginning of the so-called zero interest rate policy (ZIRP). It was clear that the economy was in a very weak state. At the time, the GDP growth rate was thought to have shrunk for five consecutive quarters since 1997:IV. ${ }^{13}$

By the spring of 1999, the decline in economic activity became clearer - the instability of the Japanese financial system became acute as the Long-term Credit Bank teetered on bankruptcy; bills to strengthen the financial system were debated in the Diet; and the international financial system was shaken by the de facto default of the Russian debts in August. ${ }^{14}$

After ZIRP was adopted, the Board members were divided into three groups, according to the disclosed minutes. Ms. Shinotsuka, who opposed adopting ZIRP, thought that the interest rate should be raised, partly to help pensioners. Mr. Nakahara, who had proposed lowering the interest rate more aggressively than other members before February, frequently put forward a motion to adopt quantitative easing and inflation targeting, as actions beyond ZIRP. Both proposals were voted down with only 1 vote in favor. The majority did not recognize the need to adopt any further actions between February and September.

Since the economy was not responding to the low interest rate, the government and business sectors began to press the Bank of Japan to adopt more aggressive quantitative easing. Just before the September 21, 1999 meeting of the Policy Board, speculations were abundant in press predicting that the Policy Board would adopt some sort of quantitative easing, possibly non-sterilized intervention in the foreign exchange market in cooperation with the Ministry of Finance. The market regarded that non-sterilized intervention to be a signal that the Bank of Japan would fight deflation with unconventional measures. The markets also focused on whether the Bank of Japan would increase the amount of money market liquidity on the settlement day that was two days after the intervention.

The Policy Board reacted strongly to this speculation in the press. The Board issued the statement, in addition to a brief announcement of the monetary policy decision, at the conclusion of the meeting, instead of waiting for quick minutes to be released two days later. In the announcement, the Board emphasized that monetary policy would not respond to exchange rate movements, that non-sterilized intervention was not a useful policy, and that the press was greatly mistaken in its reports on what would happen at the up-coming meeting. The Board indicated that it had done enough in easing monetary conditions, and it barely concealed the desire to go back to the positive interest rate by emphasizing the "side-effects" of ZIRP.

of Japan will, by paying due consideration to maintaining market function, initially aim to guide the above call rate to move around $0.15 \%$, and subsequently induce further decline in view of the market developments." (Bank of Japan, Announcement of Decisions, February 12, 1999)

13 At the time of spring 1999, the growth rates of five quarters from 1997:IV through 1998:IV were estimated as negative. The current (spring of 2004) estimates for the same period are 0.7, - 1.0, -1.1, 0.8 and 0.1. The reasons for the difference are explained in the earlier footnote. 14 Some speculate that there was also implicit political pressure from the meeting between the Finance Minister of Japan and the US Treasury secretary on September 4. 
The Board challenged the market expectation that non-sterilized intervention was to be pursued. It took a position that the exchange rate was one of the variables to be monitored, but monetary policy should not particularly respond to the exchange rate movement, per se. ${ }^{15}$ The Board then explained that non-sterilized intervention was not a useful concept for the central bank that watches total funds in the market, whatever various sources it came from. ${ }^{16}$ In addition, the Board statement contained cautionary comments on the side effects of ZIRP, a forerunner to ending the ZIRP eleven months later. ${ }^{17}$

The Board expressed displeasure on press reports and market reaction in strong words: "In the past few days, the market has substantially fluctuated by speculations on monetary policy. What should be clear is that the conduct of monetary policy is exclusively decided by majority vote at the Monetary Policy Meeting, a regular meeting of the Policy Board. It is never the case that our policy is determined in advance or in consultation with outside bodies. We would like to emphasize this point." (Bank of Japan, “On the Current Monetary Policy” September 21, 1999)

The quotes from the statement vividly illustrated the position of the Board. Any reporting of the expected decision was considered to be a challenge to independence. The Board successfully extinguished any expectation in the market that the Bank would be accommodative in response to desires from the government or the market. Any doubt about independence was erased on September 21, 1999. However, their own strong words might have trapped the Board members: that is, they could not change their positions in the following months.

Between the fall of 1999 and the summer of 2000, there was no additional easing, except for liquidity injections to deal with $\mathrm{Y} 2 \mathrm{~K}$ concerns. The government wanted some sort of additional measures of monetary easing, while the Governor increasingly mentioned the possibility of lifting ZIRP. At this point, the Bank explained that the Bank would continue ZIRP "until deflationary

15 "The foreign exchange rate in itself is not a direct objective of monetary policy. One of the precious lessons we learned from the experience of policy operations during the bubble period is that, monetary policy operations linked with control of the foreign exchange rate runs a risk of leading to erroneous policy decisions. Having said this, it does not mean that monetary policy is pursued without any consideration to the development of the foreign exchange rate. The Bank considers it important to carefully monitor the development of the foreign exchange rate from the viewpoint of how it affects the economy and prices." (Bank of Japan, “On the Current Monetary Policy” September 21, 1999)

16 "In relation to the foreign exchange rate policy, we have heard arguments in favor of non-sterilized intervention. In the reserve market, however, there are various flows of funds such as currency in circulation and Treasury funds other than those resulting from the intervention. The Bank conducts its daily market operations taking into account all the money flows, in order to create ample reserves to such an extent as described above. This strong commitment of fund provision is consistent with the government's current foreign exchange rate policy" (Bank of Japan, "On the Current Monetary Policy” September 21, 1999)

17 "The Bank views the current state of the Japanese economy as having stopped deteriorating with some bright signs, though a clear and sustainable recovery of private demand has yet to be seen. In pursuing the zero interest rate policy, we need to carefully examine its adverse side-effects, but deem it important to support the economic recovery by continuing easy monetary policy for the periods ahead." (Bank of Japan, "On the Current Monetary Policy" September 21, 1999) 
concerns subside". The economy started to show some sign of recovery in the spring of 2000, ICT-related stock prices went up and the Nikkei 225 increased by 30\% between March 1999 and March 2000. Corporate profits rose and corporate investment showed signs of recovery. There was an argument that these corporate earnings would trickle down to households to stimulate consumption sooner or later. ${ }^{18}$ This argument was dubbed the "dam theory": water was filling the corporate dam and would overflow sooner or later. Governor Hayami, believing that this was communication with the market, frequently suggested that there were bright signs in the economy and, as a consequence, there would be a possibility of raising the interest rate. Critics thought it was premature to talk about lifting the interest rate, and any mention of it itself diminished the effect of ZIRP by limiting its effects through expectations that easing would continue into the future.

The ZIRP was lifted in the Policy Board meeting of August 11, 2000. ${ }^{19}$ At this point, the continuation of a recovery of the Japanese economy was at best doubtful. First, the ICT bubble had ended and stock prices in the United States and Japan were heading down, suggesting investment and consumption would be adversely affected in the near future. Second, the US economy was beginning to show weakness, and Japanese exports to the United States were expected to decline in the future. Third, the inflation rate was still negative, and there was no sign of an end to deflation. Critics of the Bank thought that ending ZIRP was a mistake. Indeed, the government exercised an option, specified in the Bank of Japan Law, to put forward a motion for delaying voting of the proposal of raising the interest rate until the next meeting. The government motion was overruled by the Board by an 8 to 1 vote, and then the lifting of the zero interest rate policy was decided by a 7 to 2 decision.

Almost as soon as the interest rate was raised in August, the Japanese economy entered into a recession. It was not known at the time, but the official date for the peak of the business cycle turned out to be October 2000. The growth rate of 2000:III turned negative, which was offset to some extent by a brief recovery in 2000:IV. But, as the economy turned into a recession, the criticism of the Bank of Japan actions became stronger.

The economy weakened substantially toward the end of 2000. Many urged changes in monetary policy. Some economists had recommended the return to ZIRP and others recommended quantitative easing and unconventional monetary policy including increasing the amount of regular purchases of long-term government bonds, and newly purchasing listed mutual funds of stocks,

18 "Currently, it is our judgment that Japan's economy is at the stage where the number of firms taking the offensive has started increasing, that is, the economy is moderately recovering parallel with structural adjustment. ... with respect to the recovery of private demand, it seems natural that the corporate sector, which has regained profitability as a result of restructuring, should take the lead by increasing investment followed by the household sector as income conditions gradually improve. This is the development we are now witnessing." (Speech given by Masaru Hayami, Governor of the Bank of Japan, at the Japan Center for Economic Research on May 29, 2000, http://www.boj.or.jp/en/press/00/ko0005b.htm\#0103 ) 19 Governor Hayami intended to raise the interest rate in July. However, a large department store, SOGO, failed and the economy showed some weakness. The plan of lifting the interest rate was postponed without being submitted to the meeting. 
foreign bonds, and even real estate funds. These unconventional monetary tools had been rejected by Bank of Japan economists earlier.

As 2001 started, many indicators were showing weakness and the Bank of Japan decided to ease. The question then was whether to go back to the ZIRP or to introduce a new framework, quantitative easing. In February, the Bank introduced the so-called Lombard lending facility as well as cutting the official discount rate from $0.5 \%$ to $0.35 \%$. The Lombard lending facility was to lend automatically to banks with collateral at the official discount rate, so that the interest rate would be capped at $0.35 \%$. However, the market rate was at around $0.2-0.25 \%$, so there was little real impact from the introduction of the Lombard facility. Pressure to ease monetary conditions did not stop because of these measures in February 2001.

The Policy Board meeting of March 19, 2001 turned out to be the beginning of quantitative easing as well as further easing in terms of the interest rate. The target inter-bank rate was lowered immediately to 0.15 percent, and would go down to zero, as conditions warranted. The official discount rate was cut to $0.25 \%$. However, the policy change was not announced as just a return to ZIRP. It was billed as a change in the monetary policy instrument. The instrument was changed from the short-term interest rate to the balance of current accounts at the Bank of Japan. The target of the current account was set at 5 trillion yen. However, by targeting an amount beyond required reserves (about 4 trillion yen), it effectively meant that the interbank rate (i.e., the call rate) would go to zero. This amounted to excess reserve targeting. ${ }^{20}$ In September 2001, the official discount rate was cut to 0.1 percent, but this did not have any impact.

The Bank has also made clearer the conditions when it would lift ZIRP in the future. When the Bank of Japan adopted ZIRP for the first time in February 1999, the condition for lifting ZIRP was when deflationary concerns were dispelled. When the ZIRP was effectively reintroduced in March 2001, the condition became more concrete: Excess reserve targeting, or de facto ZIRP, would not be abandoned until the inflation rate, measured by CPI excluding fresh food, became stably above zero. The exit condition would be further clarified in October 2003, to be explained later.

From March 2001 to March 2003, quantitative easing was expanded in several steps.

- In August 2001, another measure of quantitative easing was employed. The amount of BOJ outright purchases of long-term government bonds was raised from 400 billion yen per month to 600 billion yen per month. At the same time, the current account target was raised to 6 trillion yen (or about 2 trillion yen excess reserves).

- In December 2001, the monthly purchase of long-term bonds was increased from 600 billion yen

20 Earlier than it was adopted in March 2001, BOJ economist, Mr. Okina (1999) reviewed the excess reserve targeting as a possibility of next step of further monetary easing. He pointed out a few problems with this option. First, "what kind of function can be expected of excess reserves" is not known with certainty and it was identified as a problem. Second, excess reserves is not reliable "as an indicator for monetary easing." Third, Dr. Okina points out an operational hurdle. 
to 800 billion yen, the current account target was raised to 10-15 trillion yen.

- In February 2002, the monthly purchase of long-term bonds was increased from 800 billion yen to 1 trillion yen.

- In October 2002, the monthly purchase of long-term bonds was raised to 1.2 trillion yen from 800 billion yen, and the current account target was raised to 15-20 trillion yen.

There have been mixed reviews on these steps. Although these steps expanded quantitative easing, especially in the amount of long-term bonds from 400 billion yen per month in September 2001 to 1.2 trillion yen per month in October 2002, deflation worsened. Some argue that this shows that quantitative easing did not work. However, advocates of quantitative easing would say that these actions prevented a major decline in economic activities.

These measures are summarized in the Figure 3. The top chart shows the expansion of purchase of long-term bonds and current account target, while the bottom chart shows the movements of the official discount rate and the call rate.

Insert Figure 3 about here

\subsection{Assessment of the Hayami Regime}

In the initial stage (April 1998 to March 1999) of the Hayami regime, until ZIRP was adopted, many Bank of Japan officials expressed a negative view toward further easing (zero interest rate and quantitative easing including base money expansion, government bond and equity purchases), indicating that it was either ineffective or would have undesirable side effects, including the risk of high inflation. ${ }^{21}$ The call for easing by scholars was being rebuffed. (See Krugman (1998), Meltzer (1998), McKinnon and Ohno (1997) for the calls for monetary easing; and Okina (1999a, b) for the

21 One such cautious opinion was expressed in July 1999 by Kazuo Ueda, a former University of Tokyo professor, a newly appointed Policy Board member. "The policy to increase the money supply would first create some decline in the call rate, but automatically create further rate declines if the economy worsens and the demand for money declines. In this sense the commitment to avoid deflationary forces is stronger with money supply targeting. ... To the extent that the money supply works through interest rates, the commitment money supply targeting delivers is already contained in the current policy stance. ...The argument that an increase in the growth rate of the money supply increases inflationary expectations and stimulates aggregate demand by lowering real interest rates sounds attractive. It is unclear again, however, how this mechanism works when the nominal interest rate has been already driven down to zero. ... How about a policy of letting the monetary base grow at 20 or $30 \%$ then? Inflation does not seem to be on the horizon. One can tighten after the inflation rate reaches 1 or $2 \%$. We think such a policy would have a small chance of success for reasons already mentioned. When it does succeed, it will probably generate a much higher rate of inflation than 1 or $2 \%$. Because of lags in the effects of policy, the $20-30 \%$ money growth will continue to generate inflationary pressure even after the tightening starts." (Kazuo Ueda, Member of the Policy Board of the Bank of Japan, at the Meeting on Economic and Financial Matters in Kagoshima, on July 1, 1999, http://www.boj.or.jp/en/press/99/ko9907a.htm ) 
rebuff.) When ZIRP was adopted in the spring of 1999, the Bank maintained the view that no further steps were needed. The Bank strongly resented any pressure or even suggestion from outside on further easing, as shown in the episode of their complaining about the speculation of easing before the Meeting in September 19999. In the spring of 2000, Governor Hayami started to suggest ending ZIRP. Most likely, he wanted to communicate with the market on the Bank's future intentions, in order to avoid a "surprise" reaction of the market and resulting volatility in the money and capital market. However, this suggestion certainly diminished any beneficial effects of ZIRP because it created expectations of higher interest rates in the future. The interest rate was raised in August 2000 despite the opinions by many scholars and the government of the need for further easing. In an international conference sponsored by the Bank of Japan in July 2000, many scholars and foreign participants were critical of the past and current policy of the Bank of Japan: Meltzer (2001), Goodfriend (2001), Svensson (2001) (note the publication date of these papers was in 2001, but the conference took place in July 2000, one month before the ZIRP was reversed). Oda and Okina (2001) compare various policy options of monetary easing and their associated risks. The authors emphasized more the risks than benefits of policy options proposed to the Bank of Japan by "academics". They argued that "introduction of a temporary fixed exchange rate system and a huge increase in the outright purchase of medium- and long-term government bonds can induce relatively large effects, although the uncertainty in the effects as well as the accompanied costs and risks may be very large." One of the discussants, Jack Beebe (2001), felt that the "authors' views of policy feasibility and risks are unduly pessimistic. ... Thus, the risks inherent in taking further policy actions need to be balanced against the risks of not taking them." What is striking is that the conference at which this debate took place occurred one month before the interest-rate hike when ZIRP was exited, which we view was a clear policy mistake.

When the ZIRP returned with quantitative easing (current account balance of 5 trillion yen implying the excess reserve of 1 trillion yen) in March 2001, the Bank did not explain why the change in policy would be effective, and this was particularly important because the Bank had not been positive on its effectiveness in the past. In the summer to fall of 2001 , there were calls for further easing by raising the current account target increase, increasing bond purchases, and purchasing equities and foreign bonds. Bank economists were negative on these suggested actions, saying that it was impossible to raise the current balance target (no buyers of short term paper with zero interest rates), or no effect beyond stabilizing the financial system, and that risk of possible deterioration of balance sheets would be serious. ${ }^{22}$ The policy started to change in December 2001, when the current

22 "Three options for further monetary easing can be considered when money market interest rates are near zero. ... Third, the BOJ can carry out unconventional operations by purchasing assets other than short-term Japanese government securities. ... The third policy option is for a central bank to purchase non-traditional assets such as government bonds, foreign currencies, corporate bonds, stocks, or real estate which are more imperfectly substitutable for base money than are short-term government securities. As stated above, central bank operations that amount to the exchange of perfect substitutes produce little effect on the 
account target was raised and long-bond purchases were raised in several steps. What was branded impossible was now possible, and the concern about the balance sheet, emphasized earlier by the Bank itself, was buried without addressing it formally.

In September 2002, the Bank started to purchase equities that the commercial banks held but wanted to dispose of in light of declining stock prices. Earlier, the Bank had denied any possibility of purchasing stocks. ${ }^{23}$ The action was justified by the Bank on the ground that it would reduce the risk of commercial banks' balance sheets, and it was made clear that it was not intended as monetary policy, but rather as financial market stabilization policy. (The decision was not made by the Monetary Policy Board Meeting -equivalent of FOMC_-but the regular Board Meeting.) However, it was not explained why the resulting risk to the BOJ balance sheet due to financial stabilization policy was not a big concern, while it was for monetary policy.

In October 2000, the Bank paper "On Price Stability" emphasized that it would be difficult to focus on a particular price index as a guide to policy. Earlier, the Bank was quite negative on the idea of inflation targeting. However, in March 2001, the Board decided to adopt the ZIRP plus quantitative easing until the CPI excluding fresh food showed a positive inflation rate "stably above zero." This seemed to be a welcome switch from negative to a positive attitude toward selecting a price index and targeting a numerical number, but the switch was not explained. In sum, the Bank has been changing its position and action, but the switch was not explained well, and contributed to the decline in the credibility of the bank.

\subsection{Fukui Regime}

The new Governor Toshihiko Fukui took over the leadership of the Bank of Japan at the maturity of the five year term of Governor Hayami in March 2003. Two deputy governors were also replaced. One of the two new Deputy Governors is Mr. Toshiro Muto who was earlier Vice Minister of Finance; and the other Dr. Kazumasa Iwata, a former professor of economics. Dr. Iwata has been

economy. Such non-traditional operations are effective because they directly alter the prices of the assets in question. Possible benefits and costs of this monetary policy option, however, are extremely uncertain."

(Kazuo Ueda, Member of the Policy Board, at the semi-annual meeting of the Japan Society of Monetary Economics held at Fukushima University in Fukushima City on September 29, 2001, http://www.boj.or.jp/en/press/01/ko0112a.htm\#0301 )

23 Governor Hayami denied the possibility of purchasing stocks as early as 1998, and repeatedly opposed to this saying that it violates the law. "There is intrinsically a very strict limit as to the extent to which a central bank can take on private sector risk. By shouldering such risk and seeing a subsequent deterioration in our assets, we might lose the confidence placed in us to fulfill our fundamental mission. Hence, the new Bank of Japan Law (effective April 1998) prohibits the Bank from purchasing equities bearing large credit and price risks. We thus do not think it appropriate to purchase corporate debt and equity. (A summary of the speech given by Masaru Hayami Governor, the Bank of Japan to the Kisaragi-kai meeting in Tokyo on December 22, 1998)_ http://www.boj.or.jp/en/press/98/ko9812a.htm. The switch in fall of 2002, why Governor changed the opinion and the purchase became possible without changing the law, was not explained. 
known to favor inflation targeting.

The new team moved quickly to increase the current account balance at the Bank of Japan. The target amount was raised from 15-20 trillion yen, at the time of March 2003 to 30-35 trillion yen as of January 2004. The amount of long-term bond purchases was not changed.

The biggest change has been the rhetoric. Governor Fukui has made it explicit that the Bank should maintain ZIRP until the inflation rate was clearly above zero. He seems to indicate commitment of ZIRP into the future, a sort of commitment recommended by inflation target advocates, or even better. ${ }^{24}$

Although the new policy is a big improvement over the last regime, there was some room for improvement. The tolerance of inflation was not indicated with precise numbers. Therefore, it was less credible than otherwise. One answer to such a criticism is the policy announcement of October 2003. It laid out the conditions for raising the interest rate:

"First, it requires not only that the most recently published core CPI should register a zero percent or above, but also that such tendency should be confirmed over a few months.

Second, the Bank needs to be convinced that the prospective core CPI will not be expected to register below a zero percent. This point will be described in such materials as the analysis and the forecasts of Policy Board members in the Outlook Report. To be more specific, many Policy Board members need to make the forecasts that the core CPI will register above a zero percent during the forecasting period.

The above conditions are the necessary condition. There may be cases, however, that the Bank will judge it appropriate to continue with quantitative easing even if these two conditions are fulfilled.” (Bank of Japan, Monetary Policy Committee announcement, October 13, 2003)

Despite the good performance in the GDP growth rate in 2003:IV, the financial and capital market participants expect that ZIRP will continue for a long time. This is a big change from the Hayami regime. So far, credibility of the Bank of Japan to maintain ZIRP seems to be on the rise.

The recent history of Japanese monetary policy has created two basic problems for the Japanese monetary authorities today. First, the Bank of Japan's policies have left Japan in a prolonged deflationary environment in which conventional monetary policy through lowering the short-term interest rate is no longer effective because the policy rate has hit a floor of zero. Second,

24 In his speech to economists, Fukui (2003) tried to put a spin that the exit-from-ZIRP condition that the Bank had adopted was more tolerant to inflation than a usual inflation target: "Assuming that a target has been established (for example, at 2 percent), if the expected inflation rate rises above the target and the Bank does not start tightening at that early stage, the actual inflation rate is likely to go beyond the target. Since the Bank's current policy commitments do not assume such a tightening at an early stage, they actually run a risk in the direction of greater inflation than in the case of standard inflation targeting" 
past Japanese monetary policy, particularly under the Hayami regime, has left the Bank of Japan with a severe credibility problem in which the markets and the public are unconvinced that Japanese monetary policy can be committed to future expansion that would return the economy to health. Both of these problems present the Bank with particular challenges in getting the economy out of deflation quickly, a subject we will return to later in the paper.

\section{Why Taylor Rules Are Not the Way to Assess Japanese Monetary Policy}

In assessing the conduct of Japanese monetary policy over the last twenty years, the following questions arise:

(1) Whether the Bank of Japan should/could have taken stronger actions against the genesis of the bubble?

(2) Whether the Bank of Japan should/could have eased earlier in the 1992-1998 period in the aftermath of the burst bubble, in order to prevent the economy falling into deflation?

(3) Whether the Bank of Japan should/could have adopted the zero interest rate policy earlier than February/March 1999 in its fight against deflation (as a prevention or as a cure)?

(4) Whether it was a mistake to raise the interest rate amid deflation in August 2000?

(5) Whether the Bank could have pursued non-conventional policy, beyond what was actually implemented in 2001-2003 to prevent a deflationary spiral (self-fulfilling expectation) from settling in?

The Taylor rule has been a popular tool to assess the monetary policy stance. The nominal interest rate is regressed on the GDP gap and the deviation of the inflation rate from the target inflation rate, along with the constant term that represents the long run equilibrium real interest rate and the target inflation rate. The Taylor rule might make it possible to judge whether the monetary policy was too tight or too loose for a particular period assuming that the estimated coefficients—either for an entire sample period or a part of it, or in some cases from other countries-represent a "normal" response of the central bank. The deviation from the estimated (fitted value) target interest rate is interpreted for too tight or too loose monetary policy. The simplest version of the Taylor rule regression is as follows.

$$
i_{t}=r^{f}+\pi^{*}+\beta_{y} \cdot y_{t}+\beta_{\pi} \cdot\left(\pi_{t}-\pi^{*}\right)
$$

wehre $i_{t}$ is the policy nominal interest rate; $r^{f}$ is long-term equilibrium interest rate; $\pi^{*}$ is the target inflation rate; $\pi_{t}$ is the inflation rate; and $y_{t}$ is the GDP gap (the log difference of the GDP and the potential GDP). In short, the nominal interest rate is regressed on the constant term, the GDP gap, 
and the inflation deviation, and in some cases the asset prices or the exchange rate. When equation (1) is regressed for a period in which the central bank has been operated under a stable regime, then the equation with estimated coefficients are viewed as a "reaction function" of a central bank.

Then, the fitted value of the left hand side variable is considered to be target interest rate (normal interest rate) that the central bank on average would have pursued if the reaction function was followed without a deviation. If the average is interpreted as optimal, then the Taylor equation gives the normative content. When the actual interest rate is below the target policy rate (the fitted value) at period $t$, then the monetary policy is judged to be more relaxed, compared to other periods. Then monetary policy that is more relaxed was judged as too lax. Similarly, when the actual interest rate is above the target rate at period $t$, then monetary policy at $\mathrm{t}$ is judged to be too tight.

Bernanke and Gertler (1999) showed that monetary policy was too lax in 1989-1990, and too tight from 1992 to 1996. Okina and Shiratsuka (2002) criticized Bernanke and Gertler (1999) for their recommendations of early tightening in the mid 1980s to prevent asset inflation was impractical. Okina and Shiratsuka think that the forward-looking inflation rate (with rational expectation assumption) is a source of problem.

Okina and Shiratsuka $(2002,2004)$ and Okina, Shirakawa, and Shiratsuka (2001) have examined monetary policy from the mid-1980s to 2002 and explored several policy options. They tend to show that monetary policy in the mid-1980s was a mistake in the sense the bubble was formed, but monetary policy in the mid- to late-1990s was basically right, and monetary policy after ZIRP does not have policy options.

Reifschneider and Williams (2000) quantified the effects of the zero bound on macroeconomic stabilization capability. They argue that under a severe contraction, open-market operations alone may be insufficient to restore equilibrium. The Taylor rule should be modified to take into account the zero bound.

Harrigan and Kuttner (2004) applied the coefficients from the US and simulated the path of the interest rate, and came to a conclusion: Had the overnight rate been set according to the Fed's policy rule, it would have been reduced to zero by mid-1993, and remained there at least through 1995.

Indeed, learning lessons from the Japanese situations was a popular exercise in the United States with an intention to avoid deflation. Clouse, et al (2000) went through a menu of options that the central bank can think of adopting at the zero interest rate, and Ahearne et al. (2002) critically evaluated the Bank of Japan policy. The latter came down to a conclusion that the Japanese monetary policy was too tight from 1992 to 1995. Bernanke and Gertler (1999), Jinushi et al. (2000), McCallum (2003), and Taylor (2001) obtained a similar conclusion that monetary loosening after 1992 was too slow (with varying changes of degree and period).

Kamada (2004) shows various estimates depending on various assumptions on output gap and data availability for decision making. Most of the simulated results show that the target rate in 
2000 remained negative, suggesting that lifting ZIRP in August 2000 was a mistake, although he refrains from such an interpretation.

Clearly, researchers have come to quite different conclusions using estimates of Taylor rules. Can this evidence be considered to be reliable? We have our doubts. To illustrate this we estimate a regular Taylor equation to examine the crucial assumptions and consequences. The following is the basic data definitions: the interest rate is the call rate (collateralized call rate until June 1985, and uncollaterilized call rate after that month); the price index is either the CPI excluding fresh food or the GDP deflator, measured as the change over the same month/quarter of previous year.

First, the GDP gap is estimated with an assumption that the potential GDP grows with a growth rate of moving average of the past growth rates in the sample. The potential output is further adjusted partly with the actual output with weight of 0.9 to long-run potential output and 0.1 to the output level of $\mathrm{t}-1$ :

$$
Y_{t}^{*}=\left(1+g_{t-1}\right) \cdot \exp \left[\lambda \cdot \ln Y_{t-1}^{*}+(1-\lambda) \cdot \ln Y_{t-1}\right]
$$

where $Y_{t-1}$ is the real GDP of $\mathrm{t}-1, \lambda$ is a set a parameter of partial adjustment and here set to be 0.9 . and $g_{t-1}$ is defined as

$$
g_{t-1}=\frac{1}{t-1} \cdot \sum_{j=0}^{t-1} g_{j}
$$

Although this is an ad hoc way to define potential output, it does capture a gradual decline in potential output in the 1990s without imposing perfect foresight or perfect hindsight, and allowing for the possibility that the 1990s were always below potential (lost decade) rather than imposing a restriction that some years have to be above potential. As McCallum (2003) pointed out, using a HP filter or a curve fitting method implies that some years have to be above potential and not appropriate in the situation that the last set of observations are suspected as being below potential significantly. Figure 4 shows our estimate of GDP gap.

\section{Insert Figure 4 about here}

We will use an inflation gap that is either backward- or forward-looking. The target inflation rate is assumed to be $2 \%$. The target long-term real interest rate is implied from the estimated constant term, namely, the estimated constant term less $2 \%$. In order to examine what the target rate should have been for a Taylor rule ignoring the zero bound, we estimate the equations using the data from 1982:I to 1994:IV.

Table I is the result of this estimation. The upper panel is the set of estimations with backward looking models, while the lower panel is the set of estimations with forward looking model. 
For the price index, the GDP deflator, CPI, and CPI excluding fresh food, are used. The GDP gap is not significant in the forward-looking regressions.

Table 1 about here

Figure 5 shows the target rate (depending on the forward and backward inflation rate) compared to the actual rate. The graph shows the following property. According to the graph, with an interpretation of the target interest rate (with backward inflation rate) to be a desirable rate, it can be said that the monetary policy was too loose from 1988-89, just about right from 1992-1995; too tight (!) in 1996-97. However, after 1999, that target interest rate is negative, suggesting that the zero interest rate policy should be maintained. The Taylor rule estimates suggests lifting of the zero interest rate toward the end of 2000 , although very briefly and very slightly above zero. ${ }^{25}$

For the reasons we outlined in the previous section, we are doubtful about this conclusion.

Figure 5 about here

Figure 5 (lower panel), the forward-looking model, shows that the "target rate" has been consistently above the actual rate since 1995, either with the GDP definition or with the CPI definition. We again are suspicious of this result. The forward-looking model did not have a significant estimate of the GDP gap.

Figure 5 (upper panel), the backward-looking model, shows that the GDP deflator model has a negative target rate since 1998. However, it shows a positive target rate during 1997-1998 period. The CPI model shows that the target rate has become positive since 2002. Both of these results are counterintuitive.

The above results suggest that we should be quite skeptical of estimated Taylor rules as a measure of optimal monetary policy stance. This does not surprise us because there are theoretical reasons for doubting the usefulness of Taylor rules to assess monetary policy, many of which have been outlined by Kuttner and Posen (2004). First, the Taylor rule is essentially a reaction function, and not an optimality condition. Unless the average monetary reaction for the period of estimation is $a$ priori known as the best practice, one cannot interpret it as the optimum, and any deviation cannot be evidence of too tight or too loose. Second, estimates are often quite sensitive to the estimation period, and that is not reassuring for us to use any particular regression results confidently without checking robustness. Third, the output gap, an important component of the Taylor rule equation, is difficult to estimate. Fitting a linear trend or more sophisticated curve (e.g., HP filter) is unlikely to give us a

25 Ueda (2000) cited an internal study of the Taylor rule in his argument for arguing against lifting the zero interest rate policy. See the next footnote for detailed quotes. 
correct output gap if years near the end of the sample is unusual (either in the upward or downward direction). For example, during the late 1990s, any conventional measure of GDP gap (or NAIRU) in the United States was indicating an overheating that would require monetary tightening. However, in view of strong productivity increase, later known as a new economy, Federal Reserve did not tighten monetary policy, and strong economic growth was extended without inflation until 2000. This episode shows the difficulty in estimating mechanically the output gap. Fourth, there are some deep conceptual problems in even deciding what an appropriate measure of the output gap is. Fifth, the regular Taylor rule estimation does not assume that the nominal interest rate is bounded at zero. Therefore, in case of Japan, the target rate estimated from the Taylor rule, without imposing the zero bound, often shows that the rate should be negative - this is regarded as evidence for keeping the rate at zero, as illustrated above. ${ }^{26}$ However, this is not rigorous. If the Taylor rule is to be interpreted as an optimal monetary policy, the zero constraint of the nominal interest rate should be included in the estimation itself. Policy advice that the interest rate should be lowered more quickly than when the inflation rate is very low cannot be obtained from a regular Taylor equation that does not impose the zero bound condition.

Our examination of the Taylor rule exercise above leaves us with a skeptical view of the use of this model to assess Japanese monetary policy. An alternative approach that we find very attractive is that in Kuttner and Posen (2004) which look for deflation scares, sharp declines in long-term bond prices when there was no increase in the short-term policy rates. Indeed, Kuttner and Posen (2004) come to a similar view of the Hayami regime. Monetary policy during that period weakened the credibility of the Bank of Japan to overcome the deflationary environment, and the abandonment of ZIRP in August 2000 was a clear policy mistake that led to entrenched expectations of continuing deflation.

\section{How Costly is Deflation?}

We have seen that Japan's deflation has been accompanied by weakness in the economy. However, does this mean that deflation has been harmful in Japan? Furthermore, even if deflation has had serious negative consequences for Japan, does that mean that deflation is always costly?

26 An interpretation of negative target rate under the Taylor rule as a suggestion for keeping the zero interest rate policy in Japan has been mentioned in Ueda (2000, September 22) who had voted against lifting ZIRP a month earlier: "the [output] gap is larger, on the deflationary side, by about $4 \%$ than the neutral level. With a coefficient of $50 \%$ on the gap in the Taylor rule formula, the gap term already contributes $-2 \%$ to the interest rate. The inflation term also contributes negatively ... Thus, there is no chance for the Taylor rule rate to become positive under such assumptions." A similar view was expressed by "one member" in the Monetary Policy Board meeting that reinstated ZIRP on March 19, 2001: "This member said that, according to this member's simulation applying the Taylor rule, when the economy recovered in the future, termination of the policy when the inflation rate was slightly above zero percent would not be premature." 
When is a deflation likely to be harmful and thus to be avoided, and when not? There are several potential costs to deflation and we look at each of these in turn.

\subsection{Deflation and the Labor Market}

One argument for a high cost to deflation is found in the work of Akerlof, Dickens and Perry (1996). Inflation that is at too low a level (which for them is below 2\%) produces inefficiency and will result in increase the natural rate of unemployment. They argue that downward rigidity of nominal wages, which they argue is consistent with the evidence, indicates that reductions of real wages can occur only through inflation. The implication is that a very low rate of inflation might prevent real wages from adjusting downward in response to declining labor demand in certain industries or regions, thereby leading to increased unemployment and hindering the re-allocation of labor from declining sectors to expanding sectors.

The evidence for the Akerlof-Dickens-Perry mechanism through which low inflation raises the natural rate of unemployment is not at all clear cut (e.g., Lebow, Stockman, and Wascher, 1995, Card and Hyslop, 1997, Lebow, Saks and Wilson, 1999, Crawford and Harrison, 2000, and Fares and Lemieux,). Also as pointed out by Groshen and Schweitzer (1996, 1999), inflation not only can put "grease" in the labor markets and allow downward shifts in real wages in response to a decline in demand along the lines of Akerlof, Dickens and Perry (1996), but can also put in "sand" by increasing the noise in relative real wages. This noise reduces the information content of nominal wages and hence the efficiency of the process by which workers are allocated across occupations and industries. Thus, we do have some skepticsim about the Akerlof, Dickens, Perry (1996) argument which argues for keeping the inflation rate above $2 \%$. However, their work does suggest that deflation might be costly.

In Japan, downward rigidity of annual compensation may not be large since regular, full-time workers have several months of compensations in bonuses. The bonuses are known to be more flexible, reflecting the performance of companies as well as individuals. Kuroda and Yamamoto (2003a, b) argued that the impact wage rigidity on unemployment is quite small in Japan, at least among male regular workers. Wage rigidity was found to be more prominent among hourly-wage, part-time female employees. Kuroda and Yamamoto (2003c) conducted a simulation analysis to show that the downward rigidity would raise the unemployment rate by as much as 1.8 percentage points under the baseline parameters. The downward wage rigidity affects the labor market condition most for the inflation rates between 2.4 percent and 1 percent.

Whether due to the wage rigidity or to some other reasons, the unemployment rate became as high as 5.5\% in August 2002, compared to 4\% in April 1998. It appears that the Phillips curve in Japan is sharply kinked at around the zero percent, CPI inflation rate. 


\subsection{Deflation, Wealth Redistribution and Financial Instability}

Unexpected deflation has the effect of shifting resources from borrowers to lenders when there are long-term debt contracts with fixed nominal interest rates. With a lower price level, and debt fixed in nominal terms, the real burden of this debt necessarily increases. One might think that losses by borrowers would be offset by gains to lenders in the macro sense, since unexpected deflation is just a wealth transfer, or a zero-sum result. But, this is not the case because deflation can lead to financial instability which can impose large costs on the economy. This provides an even more compelling reason to worry about deflation.

The transfer of resources from debtors as a result of deflation means that they suffer a loss of net worth and a deterioration in their balance sheets. Irving Fisher (1933) aptly named this phenomenon "debt deflation" and saw it as a major factor promoting the economic downturn during the Great Depression. ${ }^{27}$ With less net worth, there is a decline in the amount of collateral a lender can grab if the borrower's investments turn sour, and the reduction in collateral therefore increases the consequences of adverse selection because, in the case of a default, losses from loans are likely to be more severe. In addition, the decline in net worth increases moral hazard incentives for borrowers to take on excessive risk because they now have less to lose if their investments go sour. The increase in moral hazard and adverse selection from deflation, then means that the financial system markets will no longer be as capable of allocating capital to productive uses, with the result that investment will decline and the economy will contract. Wealth transfers are thus not neutral because they interfere with the effective functioning of the capital markets. The Great Depression is an example of where deflation had very negative consequences for the economy (Bernanke, 1983, Mishkin, 1978, 1991, 1997), with a recent example being that of Japan (Mishkin, 1998).

Wealth redistribution from deflation also affects the fiscal position of the government. One of the largest borrowers with fixed interest rate is the Japanese government. The Japanese government has been regularly issuing long-term government bonds with fixed exchange rate. (Only in 2003, did the Japanese government started to issue inflation-indexed bonds, but the principal is protected from deflation.) Unexpected deflation during the 1990s meant that the Japanese government had an increased debt burden in real terms. In addition, since tax brackets are not adjusted for inflation, deflation meant that the government had less tax revenues (i.e., it suffered a reverse bracket creep).

\subsection{Deflation, the Zero Bound for Nominal Interest Rates and Increasing Difficulties in}

27 One might think that when both general price levels (say, CPI) and asset price levels decrease, the ratio of asset prices to CPI may not drop as much, and the debt deflation may not be so acute. However, the decrease in asset prices in Japan far exceeded CPI changes, so debt deflation was a real problem. 


\section{Conducting Monetary Policy}

When the economy falls into deflation, as it has in Japan recently and as occurred in the Great Depression in the 1930s in the United States, there is a problem that arises from the zero bound of nominal interest rate. Lenders will not accept a negative interest rate, since hoarding cash provides a higher return. Thus nominal interest rates cannot go below a floor of zero and this can throw the economy into a disequilibrium situation.

Suppose that the economy is extremely weak and the real interest rate should be very low, possibly even zero or negative, in order to stimulate a recovery. However, when deflation is under way so that expected deflation is substantial, a nominal interest rate that has hit the floor at zero leaves the real interest rate quite positive. Because of the zero bound, monetary policy is no longer able to get the real interest rate down to the equilibrium real rate that will put the economy back on track. The economy can be described as being in a "deflation trap" in which it operates below capacity with investment discouraged due to the deflationary environment.

Summers (1991) and a Board member of the BOJ (Ueda (1999)) have argued that in this situation, monetary policy becomes ineffective. ${ }^{28}$ However, we believe this argument is a fallacy for the reasons outlined in Meltzer (1995) and in Mishkin (1996), and we discuss this further below. Monetary policy works through many other asset prices besides those of short-term debt securities, and so even when short-term interest rates hit the floor of zero, monetary policy can still be effective, and indeed was so during the Great Depression (see, Romer, 1992).

Nonetheless, monetary policy becomes more difficult during deflationary episodes when interest rates hit a floor of zero because the usual guides to the conduct of monetary policy are no longer relevant. In recent years, much of the research on how central banks should optimally conduct monetary policy focus on so-called Taylor rules, in which the central bank sets the short-term interest rates at a level which depends on both output and inflation gaps. The Taylor (1999) volume is an excellent example of this type of research. However, once the interest rate hits a floor of zero, all of the research on optimal monetary policy rules represented by work of the type in the Taylor (1999) volume is no longer useful because manipulating short-term interest rates is no longer an effective tool of monetary policy, as explained in an earlier section. We will see below that monetary policy can still be effective in stimulating the economy, but central bankers now will found themselves at sea without the usual knowledge to guide them, making it harder for them to get monetary policy exactly right.

28 "Now let me briefly touch upon an academic, not a real-world question of what a central bank can do beyond zero rates if it ever wanted to ease from that point on. ...discussing money supply effects on the economy other than through interest rates. I must say they are very small once liquidity has been injected enough to maintain the zero rate. ... I hasten to add that, once the zero rate is reached and spreads over to most of the short-term interest rates, attempts to expand the money supply themselves may become unsuccessful. We have been experiencing this lately in Japan.” Ueda (1999) 


\subsection{Productivity-Driven Deflation}

There may be one type of deflation that is not necessarily harmful to the economy: when the deflation occurs as a result of an extremely favorable productivity shock. In this case, the debt-deflation phenomenon may not operate. Think of what happens to a firm which finds the prices of the goods it produces falling because of a favorable productivity shock. It is true that the real indebtedness of the firm in terms of the firm's good prices rises. However, the value of the real value of the assets will also rise by the same proportion, because the firm has become more productive. In this case, the deflation is not leading to a decline in net worth and thus does not lead to the negative consequences we described earlier. This may explain the results in Atkeson and Kehoe (2004) who find that deflation was only clearly associated with economic depressions during the 1930s. Indeed, we have seen a recent episode of deflation which does not appear to have had negative consequences for the economy, China from 1997-2003.

Also deflation which results from favorable supply shocks may also not create a problem for the conduct of monetary policy. Favorable supply shocks are likely to increase the productivity of capital and thus raise the natural real rate of interest. Thus, even with deflation, the zero-lower-bound for interest rates will not be binding and monetary policy can be conducted using the conventional interest-rate tools.

Deflation (or disinflation) due to productivity increases would be accompanied by faster growth of output. This is likely to be what happened in the United States in the second half of the 1990s with the advent of the new economy. However, deflation driven by productivity growth does not describe the situation in Japan where stagnation has accompanied deflation. ${ }^{29}$

\subsection{Bottom Line on the Costs of Deflation}

The conclusion here is that deflation which occurs as a result of a decline in aggregate demand is likely to be harmful, both because it interferes with the efficient functioning of the financial markets, but also because it makes monetary policy harder to conduct. This is exactly the situation which Japan has been experiencing recently and which the world faced during the Great Depression period of the 1930s. This provides an important rationale for being concerned about the possibility of deflation. However, deflation which results from favorable supply shocks may not be nearly as harmful to the economy.

29 Repeated reference to "supply-side factors" and "technological innovations" in Hayami's speeches in the early years was quite puzzling to say the least. 


\section{Deflation Prevention}

The experience in Japan as well as the analysis in the previous section suggests that deflation can be a serious problem with high costs to the economy, particularly when it leads to a deflation trap in which conventional monetary policy is unable to help the economy to recover. Here we examine the question of how can monetary policy be designed to prevent deflation and a deflation trap from occurring. We wait until the next section to explore what can be done to get out of a deflation trap once it occurs.

Clearly, as Ahearne, et al. (2002) have pointed out, one way to prevent deflation is for monetary policy to respond particularly aggressively when negative shocks hit the economy if the economy is already in a low inflation environment. Indeed, our discussion of the Japanese experience earlier in the paper has shown that the Bank of Japan did not do this and was continually behind the curve in easing monetary policy when deflationary shocks first hit the economy. At one point, the Bank of Japan even raised the interest rate amid deflation. Clearly, central bankers are human and do make mistakes, but can monetary policy be designed so that deflation and deflation traps are less likely?

Here we will see that putting in place a strong nominal anchor through an inflation targeting regime is an important strategy for reducing the probability that deflation will occur.

However, a key issue for such an inflation targeting regime is what is the optimal level of inflation for the target? Once we examine this issue, we go on to look at whether it would be better to have the inflation targeting regime shoot for an inflation target or a price level target?

Here we will see that putting in place a strong nominal anchor through an inflation targeting regime is an important strategy for reducing the probability that deflation will occur. However, a key issue for such an inflation targeting regime is what is the optimal level of inflation for the target? Once we examine this issue, we go on to look at whether it would be better to have the inflation targeting regime shoot for an inflation target or a price level target?

\subsection{Inflation Targeting}

As discussed and outlined in Mishkin (1999a), an inflation targeting regime involves five elements: 1) public announcement of medium-term numerical targets for the price level path or inflation; ${ }^{30}$ 2) an institutional commitment to price stability as the primary, long-run goal of monetary

30 To date all inflation targeters have chosen to target an inflation rate rather than the price level. However, logically an inflation targeter could just as easily choose to target the a path for the price level which trends upward at a chosen inflation rate as target a particular rate of inflation itself. The only difference is whether by-gones are allowed to be by-gones. We look at the question of the desirability of price level versus an inflation target later. 
policy and to achievement of the price stability goal; 3) an information inclusive strategy, with a reduced role for intermediate targets such as money growth;4) increased transparency of the monetary policy strategy through communication with the public and the markets about the plans and objectives of monetary policymakers; and 5) increased accountability of the central bank for attaining its inflation objectives.

Two features of an inflation targeting regime can help in the prevention of deflation. The fact that a central bank that announces an inflation target and is accountable for achieving this target means that it will be under greater pressure to take steps to avoid a deflation as long as the inflation target is not too low (something that we turn to shortly).

For example, consider what might have happened if the Bank of Japan had an inflation target of $2 \%$ for the CPI (the median for inflation targeting regimes) in 1992 when the CPI inflation rate was still above $2 \%$. Would that have helped the Bank of Japan guide its policy in prevention of deflation? Or, suppose that the BOJ was given a $2 \%$ inflation target, in contrast to the actual $0.3 \%$ inflation rate, as well as instrument independence in 1998 under the new BOJ law. Would that have made the Bank of Japan introduce the zero interest rate policy earlier than March 1999 and avoided lifting it in August 2000?

The inflation numbers that came in after adoption of inflation targeting would have indicated that the BOJ was not meeting its goals and pressure on the BOJ to pursue more expansionary monetary policy would have clearly increased. The likelihood that the BOJ would have lowered interest rates more rapidly and started the zero-interest-rate-policy (ZIRP) earlier than 1999 would have been high. Furthermore, it is almost inconceivable that the BOJ would have abandoned ZIRP and raised the policy interest rate in August 2000 if an inflation targeting regime of this type had been in place, since it was absolutely clear at the time that deflation was ongoing and a $2 \%$ inflation rate was nowhere in sight. An inflation targeting regime is thus likely to have prevented these Bank of Japan's mistakes after 1998 and monetary policy would have moved in the right direction far earlier. Although this counterfactual does not imply that deflation would have been avoided, the simulations in Ahearne et al. (2002) suggest that easing monetary policy earlier and not tightening in 2000 would have promoted a stronger economy and reduced the degree of deflation. If an inflation targeting regime and operational independence of the BOJ had been in place after the bubble economy burst, there is even a possibility that deflation could have been avoided altogether because the BOJ would have been under continual pressure not to get behind the curve as it did in the 1992 to 1998 period when inflation was clearly below $2 \%$.

The second feature of inflation targeting is that it necessarily focuses on the management of expectations, which is increasingly viewed as being crucial to the successful conduct of monetary policy. One consequence of the adoption of inflation targeting regimes is that it puts in place a strong nominal anchor that helps pin down inflation expectations (e.g., see Erceg and Levin, 2001). Modern 
monetary theory (see Woodford, 2003) shows that a strong nominal anchor which pins down inflation expectations has major consequences for the path of actual inflation and makes deflation much less likely. These theoretical results are borne out by recent experience where we have seen major successes in the ability of monetary policy to control inflation in many industrialized countries. We would argue that this is not because central banks have become so much more knowledgeable about the transmission mechanisms of monetary policy. What has changed in recent years is that central banks in industrialized countries have been able to put much stronger nominal anchors in place. The result is greatly improved performance on both the inflation and output fronts. This of course has been done by adoption of inflation targets, as in the New Zealand, Canada, the United Kingdom, Sweden and Australia, and to some extent in the European Monetary Union.

However, a strong nominal anchor can be put into place without a formal inflation target through direct communication with the public about the commitment to price stability and actions that are consistent with it. This is the strategy pursued by the Federal Reserve, which has as strong a nominal anchor as inflation-targeting, central banks although it is embodied in an individual, Alan Greenspan (Mishkin, 2000). ${ }^{31}$ This has worked well in the United States because Greenspan has understood and emphasized in his testimony and speeches that a central bank should be highly concerned about preventing deflation (Greenspan, 2002, 2004). However, it can be dangerous to rely on an individual to do the right thing.

Governor Hayami clearly did not understand the dangers of deflation and continually spoke about the dangers of inflation even when the problem for Japan was the opposite. Furthermore, as we have seen, the BOJ's actions under Hayami were not oriented to preventing deflation. As a result, the BOJ has had a credibility problem, particularly under the Hayami regime, in which the markets and the public did not expect that the BOJ to pursue expansionary monetary policy in the future which would ensure that deflation would end. These mistakes in the management of expectations are a key reason why Japan found itself in a deflation that it is finding very difficult to get out of. ${ }^{32}$ Indeed, one of the reasons that one of us has advocated inflation targeting for the United States is that an institutional basis for the nominal anchor is likely to remain strong regardless of who is the head of the central bank (Mishkin, 1999a, Mishkin and Posen, 1997; Bernanke, Laubach, Mishkin and Posen, 1999, and Mishkin, 2004a, b). In the case of Japan, having an inflation targeting regime would have made if far more likely that expectations would have been managed more to prevent deflation, both through

31 This does not mean that there aren't reasons for the Federal Reserve to move to an inflation target. See Mishkin (2004).

32 Bank of Japan officials have been quite skeptical of their ability to influence inflation expectation of the public. "The argument that an increase in the growth rate of the money supply increases inflationary expectations and stimulates aggregate demand by lowering real interest rates sounds attractive. It is unclear again, however, how this mechanism works when the nominal interest rate has been already driven down to zero." Kazuo Ueda, "The Bank of Japan's Forward Looking Approach" -Remarks by Kazuo Ueda, Member of the Policy Board of the Bank of Japan, at the Meeting on Economic and Financial Matters in Kagoshima, on July 1, 1999. 
actions and words, as advocated by one of us, Ito (1999).

Earlier suggestions for inflation targeting were made to help raise inflation expectation in order to get out of the deflationary trap (See Krugman, 1998.) Advocates of inflation targeting also suggested that it would be an appropriate monetary policy framework for an independent central bank in order to enhance accountability and transparency of its policy. Ito (1999) further argued that inflation targeting probably enhances instrument independence. Cargill, Hutchison, and Ito (2000: ch. 5) and Ito and Hayashi (2004: ch. 5) also reviews major issues in the debate on inflation targeting in Japan.

The Bank of Japan was not warm to inflation targeting. Many Policy Board members as well as staff economists expressed skeptical views in recorded minutes of the Policy Board meetings (See Okina (1999a, b) and Ueda (2000) for a succinct view). The skeptics argued that there was no credible tool, beyond ZIRP, to raise the inflation rate. Inflation expectations in the market would not respond to a mere announcement of the target. Therefore, committing to a target when the Bank did not have the tools to achieve it would cause the Bank to lose credibility. ${ }^{33}$

At the earlier stage, that is 1999-2000, there was also an argument that the definition of deflation was not clear: which prices should be used and what numbers should be looked at in defining deflation. $^{34}$ The Bank of Japan was also responding to new calls for more careful definitions of price stability. On October 13, 2000, two months after raising interest rates, the Policy Board issued a report called "On Price Stability." In the document, price stability was defined as a state that is neither deflation nor inflation. Its apparent tautology did not help settle the problem.

Only in March 2001 did the Bank of Japan identify the price index relevant in policy discussions as the CPI index excluding fresh food (CPIexFood). ${ }^{35}$ The relaxed monetary policy would continue until inflation rate measured by the CPIexFood would become stably above zero. In October 2003, "stably" was further defined as above zero for a few months and when there would not be no risk of falling back into deflation.

It is not immediately clear to us why the Bank of Japan was so negative toward

33 "[T]he BOJ argues, as is recorded in the minutes of Monetary Policy Meetings, that 'since we cannot explicitly show the way to achieve the desired inflation rate, such action would most likely result in the BOJ losing credibility'." (Okina, 1999, p.165) Critics argued that there are non-conventional monetary policy measures that surely make the inflation rate to go from negative to positive, the credibility argument is based on incorrect assumptions.

34 "Price indicators such as the GDP deflator, CPI, and Wholesale Price Index (WPI) often move differently. Even when these indicators exhibit the same movement, the extent to which the sound development of the national economy will be achieved may depend on such factors as whether property prices are stable or rising sharply." (Okina, 1999, p.164)

35 The Cabinet Office also changed the definition of deflation in the Appendix to the Monthly Report of March 2001 from "a state in which prices are falling while the economy is contracting" to "a state of continuing fall of prices." (http://www5.cao.go.jp/keizai3/2001/0316getsurei/main.html) 
non-conventional monetary policy and inflation targeting under the Hayami regime. ${ }^{36}$ One possible answer was that inflation targeting was interpreted as a strategy to inflate away the nonperforming loans problem. Governor Hayami repeatedly cautioned that economic boom and inflation would make problem firms survive longer: inflation would delay structural reform. ${ }^{37}$ This smacked of the view that "cleansing" was needed, which has a strong resonance to what Federal Reserve officials said during the Great Depression in the 1930s. This view clearly misinterpreted what inflation targeting is about.

Second, another possibility is that the BOJ fell into the "independence trap," as it was called by Cargill, Hutchison, and Ito (2000). Namely, the Bank of Japan was afraid to take bold actions when it had just gained independence. Before independence, a usual argument not to lower the interest rate quickly was that once it was lowered, it would be very difficult, politically, to raise the interest rate. Achieving independence was supposed to solve this problem. Flexible adjustments and bold actions were supposed to have become possible. On the contrary, the BOJ became much more conservative in the sense that it became reluctant to take actions, especially unprecedented ones, that might be judged a failure later, arguing that it would be important to establish credibility early. If this is the case, the BOJ was given independence precisely at the moment that it should not be given independence, because the economy called for unprecedented monetary policy.

Third, one more possible interpretation is that the Bank genuinely was worried about possible deterioration of its balance sheet. Purchasing a large amount of long-term government bonds would put the balance sheet at risk if they later declined in value. A question is whether stopping non-conventional monetary policy on the ground of a concern about the balance sheet is desirable from the point of view of avoiding deflation and maximizing potential output. The Bank of Japan is part of the public sector, and any losses on the Bank's balance sheet would be counterbalanced by gains on the central government's balance sheet. Since the Bank of Japan should be considered as a part of the government from an accounting point of view, concern about these losses is unwarranted, unless they created political problems for the Bank. The balance sheet of the Bank of Japan should be guaranteed by the government if it makes sense for the BOJ to take risk in its operations. ${ }^{38}$ In this

36 Ito (2004) examines why the Bank of Japan did not adopt inflation targeting, based mostly on Minutes of the Monetary Policy Meetings.

37 "When the economy recovers, as is now happening, it might well be the case that efforts for structural reform might be neglected due to a sense of security. In addition, when the shadow of structural reform becomes conspicuous, for example in employment, calls to reverse such reform and pressure for additional macroeconomic policy measures such as the expansion of aggregate demand are very likely to intensify.... Structural problems cannot be solved solely by macroeconomic policy measures such as monetary and fiscal policy. Now that financial and capital markets are highly globalized, any attempt to wipe out past problems by generating inflation will never be successful". (Speech given by Masaru Hayami, Governor of the Bank of Japan, at the Japan Center for Economic Research,

http://www.boj.or.jp/en/press/00/ko0005b.htm, May 29, 2000)

38 Under the old Bank of Japan law, before 1998, heavy losses on the balance sheet incurred by the Bank 
sense, independence came at a wrong moment in history.

\subsection{What is the Optimal Level of Inflation?}

A key issue in any inflation targeting regime, whether it targets a path of the price level or the inflation rate, is what is the optimal level of inflation that the central bank should want the price level to grow at over the long run? In order to decide on the appropriate long-run inflation goal, we need to answer the deeper question of what does price stability mean? Alan Greenspan has provided a widely-cited definition of price stability as a rate of inflation that is sufficiently low that households and businesses do not have to take it into account in making everyday decisions. This definition of price stability is a reasonable one and operationally, any inflation number between 0 and $3 \%$ seems to meet this criterion. Some economists, Martin Feldstein (1997) and William Poole (1999) being prominent examples, argue for a long-run inflation goal of $0 \%$, which has the psychological appeal of the "magic number" of zero. Indeed one concern is that an inflation goal greater than zero might lead to a decline in central bank credibility and instability in inflation expectations which could lead to an upward creep in inflation. However, evidence in Bernake, Laubach, Mishkin and Posen (1999) suggests that maintaining a target for inflation above zero, but not too far above (less than $3 \%$ ), for an extended period, does not lead to instability in the public's inflation expectations or to a decline in central bank credibility.

The Bank of Japan (2000) attempted to define price stability in October 2000. However, it concluded that the would not be appropriate to give a numerical value to price stability, a surprisingly negative attitude toward commitment to inflation targeting:

If some numerical values are adopted as the definition of price stability, they are expected to be valid for a very long period of time. In view of the current development of prices in Japan, it is difficult to set specific numerical values to the definition of price stability that are consistent with the sound development of the economy. Furthermore, even if some numerical values were announced, they would not serve as a reliable guidepost in the conduct of monetary policy, and the exercise would not likely contribute to enhancing transparency of the conduct of monetary policy. Therefore, it is not deemed appropriate to define price stability by numerical values. (Bank of Japan, 2000. Summary, Paragraph 5-(2).)

There are several reasons why the desirable target rate should be positive. First, there is an

of Japan were automatically filled by the Ministry of Finance. In the new law of 1998, since policies of the Bank of Japan were subject to direction of the Minister of Finance. The clause was eliminated in the new law that emphasizes independence of the Bank of Japan. 
upward bias in CPI by construction. ${ }^{39}$ Second, it helps the economy to achieve necessary relative price adjustment if some prices and wages are sticky downward. This is a basis of the argument in Akerlof, Dickens and Perry (1996). Third, an even more persuasive argument against an inflation goal of zero is that it makes it more likely that the economy will experience episodes of deflation. We have argued above that deflation can be highly dangerous when it promotes financial instability and in addition can make monetary policy decisions harder if as a result short-term interest rates hit a floor of zero. The implication is that undershooting a zero inflation target (i.e., a deflation) is potentially more costly than overshooting a zero target by the same amount. This can be dealt with by having a target rate with a buffer so that even some perturbation around the target would not force the economy into deflation.

The logic of this argument suggests that setting an inflation target a little above zero is worthwhile because it provides some insurance against episodes of deflation. Simulation evidence in Fuhrer and Madigan (1997), Orphanides and Weiland (1998) and Reifschneider and Williams (2000) bear this out, finding that inflation targets near zero (below 2\%) increase output variability. This is why one of us has argued in Mishkin (1999a) and Bernanke, Laubach, Mishkin and Posen (1999) for a long-run inflation goal of $1 \%$ above true inflation. The Boskin commission (Boskin et al. 1996) estimated that the measurement bias in CPI inflation was about $1 \%$ and this is why Bernanke, et al (1999) suggested a CPI inflation goal for the United States of $2 \% .^{40}$ In the case of Japan, the upward bias in measured CPI inflation over true inflation has been estimated to be 0.9\%. (Shiratsuka, 1999), although redefinition of the price CPI price index in Japan may mean that the bias is now lower. Adding this to an inflation goal of about $1 \%$ true inflation, an inflation goal of near $2 \%$ for the CPI in Japan makes sense.

Another reason why central banks might be better off with a long-run inflation goal above zero, is that it is crucial that they not be perceived as being overly obsessed with controlling inflation at the expense of output stability. If a central bank is perceived as an "inflation nutter" in Mervyn King's (1996) terminology, in which the central bank puts no weight on output fluctuations in making its decisions about monetary policy, it is likely to lose the support of the public. Too low an inflation target may signal to the public that the central bank does not care sufficiently about the public's concerns. It is unstable for a central bank in a democracy to have a very different loss function than the public (Blinder, 1998, and Mishkin, 1999b) and pursuing too low an inflation target may weaken

39 The Laspayres index tends to underestimate the true inflation by keeping the basket fixed, so that the demand shift due to the relative price changes would not be reflected. The new products would not be included. Quality improvement is often ignored.

40 Since the Boskin commission, the BLS has altered its procedures to reduce the measurement bias in CPI inflation. Also the inflation bias in the PCE deflator, which appears to be the preferred measure of inflation used by the Federal Reserve, is even lower than for the CPI. This would suggest an even lower inflation goal for this deflator. 
the support for central bank independence. ${ }^{41}$

\subsection{Price Level Versus Inflation Target?}

Currently, all countries who have adopted inflation targeting have chosen to target inflation rate rather than the price level. However, which of these two targets would result in better economic performance and prevent deflations is still an open question. Here we look at this question when the economy is assumed to be experiencing a positive rate of inflation. The answer to this question may be quite different when the economy is already in a prolonged deflation and we will address this situation in the following section.

There are two key advantages of a price-level target relative to an inflation target. The first is that a price-level target can reduce the uncertainty about where the price level will be over long horizons. With an inflation target, misses of the inflation target are not reversed by the central bank. The result is that inflation will be a stationary stochastic process, that is, integrated of order zero, $\mathrm{I}(0)$, while the price level will be nonstationary, an I(1) process. The result is that the uncertainty of where the price level will be in the future grows with the forecast horizon. This uncertainty can make long-run planning difficult and may therefore lead to a decrease in economic efficiency. Although, McCallum (1999) has argued that the amount of long-run uncertainty about the future price level that would arise from successful adherence to an inflation target may not be all that large, it still complicates the planning process and may lead to more mistakes in investment decisions.

The second possible advantage of a price-level target is that in models with a high degree of forward-looking behavior on the part of economic agents (e.g., Svensson, 1999, Woodford, 1999, 2003, Svensson and Woodford, 2003, Clarida, Gali and Gertler, 1999, Dittmar and Gavin, 2000, and Vestin, 2000) it produces less output variance than an inflation target. However, empirical evidence Fuhrer (1997) does not clearly support forward-looking expectations formation, and models with forward-looking behavior have counterintuitive properties that seem to be inconsistent with inflation dynamics (Estrella and Fuhrer, 1998).

The traditional view, forcefully articulated by Fischer (1994), argues that a price-level target might produce more output variability than an inflation target because unanticipated shocks to the price level are not treated as bygones and must be offset. Specifically, a price-level target requires that an overshoot of the target must be reversed and this might require quite contractionary monetary policy and, with sticky prices, this could lead to a sharp downturn to the real economy in the short run. Indeed, if the overshoot is large enough, returning to the target might require a deflation, which could

41 By also emphasizing that the horizon for hitting an inflation target will need to be lengthened in order not to impose large output losses on the economy if inflation is far from target, the central bank can also make clear that it does put a weight on output fluctuations in making its decisions about monetary policy. See Mishkin (2004). 
promote financial instability and be quite harmful to the economy.

Although the models with forward-looking price setting, do not find that this feature of a price-level target increases output variability, they do not focus on the fact that a price-level target may lead to more frequent episodes of deflation which lead to the problems discussed in Section II: deflation can exacerbate financial instability or can make monetary policy more difficult to conduct because interest rates cannot go below zero. These costs of deflation tend to make us more skeptical about theoretical results which indicate that price-level targets are able to reduce output variability when inflation is positive. Indeed, price-level targets which lead to more episodes of deflation may be more dangerous than their proponents have realized.

In addition, a price level target may be more difficult to explain to the public because it is a moving target, in contrast to an inflation target which is not. Because increased transparency and accountability is a highly desirable attribute for the conduct of monetary policy, this is an important advantage for an inflation target.

Another problem for a price-level target that has received little attention in the literature is the presence of measurement error in inflation. Most research on measurement error takes the view that it is inflation that is measured with error rather than the price level and this was the approach taken by the Boskin Commission. ${ }^{42}$ This implies that the measurement error in the price level is I(1) that a price-level target results in growing uncertainty about the true price level as the forecast horizon grows. Thus many of the arguments that a price-level target results in lower long-run uncertainty about the true price level may be overstated.

The conflicting arguments above indicate that whether price level rather than inflation targets would produce better outcomes when inflation is positive is an open question. Given this uncertainty about the benefits of price level targeting, it is not surprising that no central bank has decided to target the price level in recent years. ${ }^{43}$ However, the arguments made here for preferring an inflation target over a price-level target, do not rule out hybrid policies, which combine features of an inflation and a price-level target and so might provide the best of both worlds.

An inflation target could be announced with a commitment to some error correction in which target misses will be offset to some extent in the future. Recent research shows that an inflation target with a small amount of error correction can substantially reduce the uncertainty about the price level in the long run, but still generate very few episodes of deflation (e.g., Black, Macklem and Rose, 1998, King, 1999, and Battini and Yates, 1999). Furthermore, by putting a small weight on the price level error correction term, the trade-off between output and inflation fluctuations can be improved (e.g., see also Williams, 1999, Smets, 2000, Gaspar and Smets, 2000, McLean and Pioro, 2000). Evaluating hybrid policies of this type is likely to be a major focus of future research.

42 See Boskin et al. (1996), Moulton (1996), and Shapirio and Wilcox (1996), for example.

43 However, a price level target was used in the 1930s in Sweden (Berg and Jonung, 1999). 
One issue that would have to be addressed if such a hybrid policy was adopted is how it could be explained to the public. As is emphasized in Bernanke and Mishkin (1997), Mishkin (1999a), and Bernanke, et. al. (1999), critical to the success of inflation targeting is that it provides a vehicle for more effective communication with the public. The public will clearly not understand the technical jargon of error correction models. However, some form of an error correction feature of an inflation targeting regime could be communicated by not only announcing an intermediate-term inflation target, but also by indicating that there is a target for the average inflation rate over a longer period, say five years.

\section{Deflation Cures}

Once an economy begins to experience a deflation, it encounters an additional set of problems that alter the issues that confront monetary policy. First is that the economy may be in a deflation trap in which monetary policy operating through short-term interest rates is powerless to extricate the economy from the deflation because the policy interest rate cannot be driven below the zero lower bound, which leaves the real interest rate too high to stimulate recovery. Second, the central bank may have a severe credibility problem in which the markets and public are unconvinced that monetary policy can be committed to future expansion that would return the economy to health. Both of these problems are exactly what we see in Japan today. As we discussed in Section I, the Japanese economy is still experiencing deflation even though short-term interest rates are at zero, while past BOJ policies, particularly under Hayami, have suggested to the public that once there is a glimmer of recovery, the monetary authorities are likely to raise interest rates and tighten monetary policy.

Given these problems, what can be done to get the economy out of the deflationary spiral? We will discuss two key elements of strategies to cure deflation: 1) management of expectations through adoption of a price level target, and 2) nonconventional policies that employ central bank purchases of other assets besides short-term bonds.

\subsection{Price Level Target}

According to traditional monetary theory, it might appear as though monetary policy cannot be effective in escaping the deflation trap because there is no way to drive the standard interest-rate instrument below zero. However, recent literature (Krugman, 1998, and Eggertsson and Woodford, 2003, Auerbach and Obstfeld, 2003, and Svensson, 2003) suggests that there is a solution to this problem: management of expectations. If the central bank can convince the markets and the public 
there will be higher inflation in the future, then even with the interest rate at a floor of zero, the real interest rate will fall and this will stimulate aggregate demand through the usual channels (Mishkin, 1996). But how is the central bank to do this?

Once an economy has entered a prolonged deflation as it has in Japan, lowering the real interest rate to stimulate the economy requires a substantial increase in expected inflation. This is why Krugman (1998) made the radical suggestion for the BOJ to adopt an inflation target of $4 \%$ for a fifteen-year period. However, a high inflation target, as suggested by Krugman, is unlikely to be credible for two reasons. First, a commitment to a high inflation target may not be credible because it is too much at variance with a goal of price stability. As documented in Bernanke, Laubach, Mishkin and Posen (1999), no inflation targeting central bank in an industrialized country has chosen a medium-term inflation target above 3\%. Indeed, we suspect that the Krugman proposal may have increased the BOJ's resistance to inflation targeting because this level of inflation was well above what officials in the bank believed was consistent with price stability. Furthermore, once the economy has emerged from a deflationary spiral and starts to recover, the central bank will be tempted to renege on its commitment to a high inflation target because it would like the economy to return to an inflation rate consistent with price stability. Thus as pointed out by Eggertsson (2003), a central bank in a deflationary environment is subject to a time-inconsistency problem: it cannot credibly commit to "being irresponsible" and so continue to shoot for high inflation. The result of time-inconsistency problem is that the markets would not be convinced the inflation would remain high, inflation expectations would not be sufficiently high to lower real rates sufficiently to stimulate the economy out of the deflation trap.

Another problem with an inflation target is that it is not "history-dependent" because it is purely forward-looking (Woodford, 2000, 2003). An inflation target is not adjusted depending on the past outcome of inflation, and, as Eggertsson and Woodford (2003) have shown, will not be effective in extricating an economy from a deflation trap. When the interest rate has hit a floor of zero, a deflationary shock which lowers the price level and puts the economy even farther below its potential requires an even higher expected inflation in order for the real interest rate to be lowered and be even more stimulative. A price level target does exactly this: with a price level target, the same price level target implies that inflation will be expected to be higher, and this produces exactly the right response of a lower real interest rate and more stimulative monetary policy.

The theoretical argument for a price level target when an economy is in a deflationary environment is thus quite strong. But there is a further reason for adoption of a price level target when an economy has experienced a prolonged period of deflation along with a severe balance-sheet problem that prevents the financial system from working properly as in Japan (e.g., Posen, 1998, Mishkin, 1998, Hoshi and Kasyhap, 2004). In Japan, non-performing loans have weakened bank balance sheets, and the lack of capital has meant that banks have been forced to cut back on lending, 
particularly for new investment. The result is that the financial system is unable to allocate capital to productive investment opportunities, and this is a key element in the stagnation in Japan. The deflation has also weakened corporate balance sheets who have found their debt increase in value in real terms while their assets have not (the debt-deflation phenomenon described by Irving Fisher, 1933). The loss of net worth implies that even firms with good investment opportunities may then not be able to get funds at favorable rates because the firm is more likely to engage in risky (moral hazard) behavior because there is less at stake in the firm (Mishkin, 1997). Thus restoring both financial and non-financial balance sheets is crucial to helping an economy like Japan's to achieve a more efficient allocation of capital that will restore it to health.

A price level target that would get the price level to what it would have been if the economy had not experienced deflation is an important way to help restore balance sheets. A higher price level would lead to lower real indebtedness of firms and would thereby increase their net worth, making it more attractive to lend to them if they have productive investment opportunities. The improvement in firm's balance sheets would also help reduce non-performing loans which would have a positive knock-on effect on bank balance sheets, thus making it easier for them to lend.

Furthermore, after a prolonged period of deflation, an economy may need to undergo substantial restructuring if it is to return to health. Both the BOJ and commentators on the Japanese economy have stressed the need for restructuring of the Japanese economy. ${ }^{44}$ Indeed, the BOJ has continually argued that the economy cannot recover without restructuring and has worried that expansionary monetary policy was seen as an alternative to the needed restructuring and thus may be counterproductive. (This rhetoric seems to have stopped under Governor Fukui's leadership after March 2003.) Closing down inefficient firms and financial institutions may be exactly what the economy needs in the long run, but in the short-run it might lead to severe dislocations and unemployment. Indeed, this is probably why there has been so much resistance to the restructuring process on the part of Japanese politicians. Here is where a price level target to raise the price level comes in. As we have seen, a higher price level would help restore financial and non-financial balance sheets and would help the financial system to start working again to allocate capital, which is critical to a restructuring process. Also to the extent that a commitment to a higher price level by the monetary authorities helps raise aggregate demand, this would help cushion the short-term negative effects of the restructuring process. A price level target which encourages more expansionary monetary policy is thus more sensibly viewed as a complement to restructuring rather than an impediment.

The analysis above suggests that a price level target has many advantages when an economy is already experiencing deflation. Also in this case, the criticism that a price level might lead to an overshoot of the target that must be reversed, which could lead to deflation and an economic

44 See for example, Yamaguchi (1999). 
contraction is no longer valid. When an economy is in a deflation trap and is far from the appropriate price level target, the price level is necessarily lower than the target and so it promotes higher expected inflation which lowers real interest rates, and this then works in exactly the right direction to get the economy back on track. A price level target thus dominates an inflation target in a deflationary environment.

Note that since October 1997, the CPI excluding fresh food has fallen by $3.5 \%$ to the present, while annual averages, the CPI has fallen by $2.5 \%$ between 1998 and 2003. This certainly understates the amount of deflation because, as is well known, measured inflation is likely to be an upward biased measure of true inflation. ${ }^{45}$ Most estimates of measurement error in CPI inflation in industrialized countries is around 1\% and a similar finding has been found for Japan Shiratsuka (1999). Hence we regard an annual increase in measured CPI or around $1 \%$ as absolute price stability. So this would suggest that a target for the CPI would be at least $7.5 \%$ over current levels. ${ }^{46}$ However, because the price level target is a moving target it would continue to rise at the $1 \%$ rate and so the cumulative price increase when the target is reached would necessarily be higher in the future.

An illustration of how this might work is illustrated in Figure 6. Suppose that the price level target was reached by the end of 2008, as is shown by the hypothetical CPI in the figure, then the cumulative increase from now (June 2004) to December of 2008 would be 13\%, or an inflation rate of $2.5 \%$ per year over the period. If this target was credible, this would mean that even with a nominal interest rate of zero, the real interest rate would fall to $-2.5 \%$ which would be highly stimulative, exactly along the lines that Eggertsson and Woodford (2003) suggest would be appropriate.

Figure 6 about here

But what should be done once the price level target is achieved. One strand of the literature suggests that it would be optimal to continue with the price level target. In models with a high degree of forward-looking behavior (e.g., Svensson, 1999, Woodford, 1999, 2003, Svensson and Woodford, 2003, Clarida, Gali and Gertler, 1999, Dittmar, Gavin and Kydland, (1999, 2000), Dittmar and Gavin, 2000, Vestin, 2000, and Eggertsson and Woodford, 2003) a price level target produces less output variance than an inflation target.

\subsection{Nonconventional Monetary Policy}

45 The CPI excluding fresh food was 101.1 in October 1997, that turned out to be a peak. In February 2004, the index became 97.5 (3.5\% lower than 6 years ago). The annual average of 1998 was 100.4, while it was 98.0 in 2003. The CPIexFood level of 2003 was less than the peak by $2.4 \%$.

46 The gap is estimated as $2.4 \%$ (measured by the index decline) plus the inflation bias ( $1 \%$ x 5 years), that results in about $7.5 \%$. 
Critics of inflation targeting (Friedman, 2003) have argued that the concept of "managing expectations" is problematic. Why would announcing an inflation or a price level target pin down expectations? Aren't actions more important than words? Words by themselves are not enough, but neither are actions. This argues for the use of words plus actions in the conduct of monetary policy.

This raises the issue of what actions will actually influence the economy and help make a price level or inflation target credible, particularly when the policy interest rate has hit a floor of zero? Once the short-term, policy interest-rate is at the floor of zero, It clearly cannot be driven lower. Thus the conventional monetary policy tool of manipulating the short-term, policy interest rate is no longer an option. Is the central bank powerless? What nonconventional policy measures can it take to affect the economy and thereby achieve its price level or inflation target? We look at four types of measures below: 1) quantitative easing, 2) open-market operations in long-term bonds, 3) foreign exchange rate intervention, and 4) open market purchases of private, real assets.

\subsubsection{Quantitative Easing.}

The nonconventional monetary policy tried by the BOJ has been the so-called "quantitative easing." This involves an expansion of the monetary base, even when the policy interest rate cannot be driven any lower, either through open market operations on short-term government debt, outright purchase of long-term bonds (or equities), or through unsterilized purchases of foreign currency. The BOJ has been conducting such a policy since March 2001, and more aggressively since December 2001.

Figure 7 shows growth rates of monetary base (MB) and the money supply (M2+CD, hereafter simply M2). MB had indeed expanded quickly from the end of 2001, but with little impact on M2. How to explain the deviation between MB and M2 is a challenge, and another is whether an expansion of $\mathrm{MB}$ without an expansion of $\mathrm{M} 2$ has positive impacts on the economy. The monetary base includes the amount of current account at the Bank of Japan, the amount of excess liquidity in the system. In normal times, excess reserves would be unlikely to help stimulate the economy. However, an expansion of the monetary base might be beneficial even if it does not produce a significant increase in M2 when the interest rate is zero. First, ample liquidity in the system may help avoid a potential financial crisis that was a concern in 2002-2003. Second, liquidity may encourage financial institutions to take more risk in portfolio management, in particular taking positions in long-term bonds, equities, and foreign bonds, any of which would contribute to stimulating the economy indirectly. The economic recovery in 2003 may be partly due to ample liquidity in the system.

Figure 7 about here 
However, the data do not look favorable to this approach. The monetary base has increased by $20-40 \%$ from 2002 to 2003 and yet deflation did not stop. One problem with coming to this conclusion based on the evidence from Japan is that, as we have seen in the earlier section of this paper, the BOJ has created market expectations that even when it pursued expansionary monetary policy for a time, it would soon reverse it. Then it is no surprise that quantitative easing would not work.

In addition, there are good theoretical reasons why quantitative easing might be ineffective. The conventional liquidity trap analysis suggests that when the short-term interest rate hits a floor of zero, short-term bonds become a perfect substitute for money and so expanding the monetary base will have no effect on the economy. Eggertsson and Woodford (2003) show that this result can even hold if short-term bonds and money do not become perfect substitutes, although this conclusion still is based on the specific assumptions of their model. However, as they emphasize, quantitative easing might help stimulate the economy if it provided a signal that the monetary base would be higher than it otherwise would be once the deflation is over. This is the position taken by Auerbach and Obstfeld (2003).

Given that theoretical arguments against its being effective and the fact that quantitative easing has not worked to stimulate the economy and stop deflation in Japan, there is clearly a strong case that the BOJ needs to look at other approaches to conducting monetary policy.

\subsubsection{Open Market Operations in Long-Term Bonds.}

Alternative non-conventional monetary policies involve the monetary authorities in conducting open market operations in other assets besides short-term bonds. The most conventional of these is a shift toward central bank purchases of long-term rather than short-term bonds. Since, long-term interest rates are more likely to figure in household and business decisions about spending, it seems that open market purchase of these bonds might succeed in lowering long-term interest rates, thereby stimulating the economy. However, in order for purchase of long-term bonds to work there would have to be significant portfolio-balance effects, so that a shift in the supply of long-term versus short-term government debt in the hands of the public as a result of the open market purchases would affect risk (term) premiums and so result in a fall in long-term rates. However, the evidence that risk (term) premiums can be affected by changing the supply of long-term bonds relative to short-term bonds in the hands of the public is, unfortunately, far from clear. One episode where this was tried was the so-called "Operation Twist" in the United States in the early 1960s and it has generally been viewed as a failure with only a very small effect if any on the relative interest rates of long versus short-term bonds (see Meulendyke, 1998, for a summary of the literature).

Bernanke (2002) has suggested that the apparent failure of Operation Twist does not mean that the central bank could not drive long-term bond rates down as long as the central bank announced that it would peg interest rates on long-term bonds at a very low interest rate (possibly zero) and stood 
ready to purchase these any amounts of these bonds at this low rate. This peg could certainly work because the commitment is easily verifiable since the price and interest rates on long-term bonds are immediately known. However, this could require the central bank to purchase the entire stock of long-term bonds which it might not be fully comfortable about doing.

Clearly another way for the central bank to lower long-term bond rates (Orphanides and Wieland, 2000) is to convince the markets that it will continue to pursue a zero-interest-rate policy (ZIRP) for a considerable time even after the deflation is over. Then, as is suggested by the expectations hypothesis of the term structure, because long-term bond rates are an average of the expected future short-term rates, long-term interest rates would necessarily fall. Indeed, this strategy is complimentary to Bernanke's (2002) because it is a way of committing to more expansionary policy in the future even after the economy has bounced back.

The Bank of Japan's announcements about clarifying the conditions of exit from the zero-interest-rate policy have some elements of this strategy. The BOJ has effectively announced that it will not reverse the ZIRP policy until there is clear cut evidence that the deflation is over and that it is unlikely to recur in the future. However, this is a far weaker commitment than the strategy above suggests. It requires that a commitment to stay with ZIRP not only until the deflation is clearly over, but until there is a prospect of achieving the price level target described above in which the CPI would have to rise substantially to get to the target. ${ }^{47}$ There is still the problem that an announcement of this type might not be believed by the markets because of the past behavior of the central bank, and this is clearly a problem for the BOJ because of the policies under Governor Hayami where the ZIRP was reversed as soon as the economy began to recover. However, this is where the purchase of long-term bonds might help. The central bank could buy substantial amounts of these long-term bonds as a signal of its confidence that their price will remain high because ZIRP will be continued well after the deflation is over. Buying long-term bonds would also provide incentives for the central bank to stick with the ZIRP policy after the deflation is over because premature abandonment of ZIRP would lead to losses on the long-term bonds that it has bought

\subsubsection{Foreign Exchange Intervention.}

Depreciation of the currency provides an addtional way of exiting from a deflation trap. A fall in the value of the domestic currency makes imports more expensive and exports cheaper. The result is expenditure switching in which exports rise and imports fall, thereby increasing the demand

\footnotetext{
${ }^{47}$ In order not to overshoot the target, ZIRP would have to be removed a little while before the target is reached, but for all practical purposes, this would be a commitment to keep ZIRP for a substantial period after the deflation is over.
} 
for domestically produced goods which stimulates aggregate demand. Intervention in the foreign exchange market, the selling of yen and purchase of foreign currency, has thus been suggested as a powerful way of getting the Japanese economy moving again (Bernanke, 2000, McCallum, 2000a, b, 2002, 2003, Meltzer, 2001, Orphanides and Wieland, 2000, and Svensson, 2001, 2003). Indeed, in recent years the Ministry of Finance and the Bank of Japan intervened in the foreign exchange market to keep the yen from appreciating, but have not engineered a depreciation of the yen.

One problem with this transmission mechanism is that it also requires that portfolio-balance effects are operational. The exchange rate intervention in which the purchase of foreign-denominated assets are bought with domestic currency, thereby increasing the supply of domestic currency-denominated assets relative to foreign-denominated assets, only affects the exchange rate if domestic and foreign assets are imperfect substitutes. As was the case for short-term versus long-term bonds, the evidence for portfolio-balance effects are not strong (See the survey in Sarno and Taylor, 2001)

However, here is where a price level target and the management of expectations can again come to the rescue. Svensson $(2001,2003)$ has advocated that along with an announcement of a price level target along the lines we have described above, the government and/or the central bank (depending on who control foreign exchange intervention) commit to an exchange rate peg which is consistent with that price level target. This involves a commitment to an immediate depreciation of the domestic currency which would then be allowed to appreciate at the rate of the foreign interest rate differential (so that the expected return on foreign and domestic assets is equalized.) The peg would then be abandoned once the price level target has been achieved and a price level or inflation targeting regime would be put into place. Committing to the peg is also a commitment to the higher price level target and continued expansionary monetary policy even after the deflation is over. Thus it solves the commitment problem described above.

Since the policy calls for a substantial depreciation of the domestic currency from current levels, it would require that the government or central bank stand ready to buy large amount of foreign-denominated assets to ensure that they are a good investment relative to domestic-assets. This would just mean an accummulation of international reserves which is always feasible. (This is in contrast to a case where a country wants to prop up the value of its currency and thus must sell foreign assets, thereby losing international reserves which may run out and thus force the abandonment of the peg.) The commitment to a peg also has the advantage that it provides incentives for the central bank and the government to stick with the peg until the price level target is achieved: early abandonment would lead to an appreciation of the domestic currency which would result in substantial losses on the holdings of international reserves.

Although, we agree with Svensson that his "foolproof way" to escape the deflation trap would work, we do have our doubts about this strategy. Such a strategy suffers from two difficulties. First, 
the country's trading partners would be likely to be up in arms if an exchange-rate peg of this type were announced. We have seen strong U.S. complaints against the Chinese peg of the yuan at, most likely, an undervalued rate, and we expect that this outcry would be even harsher if Japan adopted Svensson's suggestion. The outcome might be trade sanctions and a rise in protectionism that could be disastrous for the world trading system.

A second problem is that adoption of an exchange rate peg might cause a shift of the nominal anchor away from the price level or inflation target to the exchange rate. For example, as part of its inflation targeting regime, Israel has had an intermediate target of an exchange rate band around a crawling peg, whose rate of crawl is set in a forward-looking manner by deriving it from the inflation target for the coming year. Even though the Bank of Israel downplayed the exchange rate target relative to the inflation target over time, it did slow the Bank's efforts to win support for disinflation and lowering of the inflation targets (see Bernanke, Laubach, Mishkin and Posen, 1999.) A recent example of this problem has occurred in Hungary (Jonas and Mishkin, 2004) which has an exchange rate band as part of its inflation targeting regime. In January 2003, the forint appreciated to the upper end of the band, and speculation about the revaluation of the parity resulted in a sharp acceleration of capital inflows that forced the National Bank of Hungary to respond by cutting interest rates by 2 percentage points and intervening heavily in the foreign exchange market. The National Bank of Hungary is reported to have bought more than 5 billion euros, increasing international reserves by 50 percent and base money by 70 percent. (See J. P. Morgan (2003)). Even though the National Bank of Hungary began subsequently to sterilize this huge injection of liquidity, market participants then assumed that maintaining the exchange rate band would have a priority over the inflation target and expected inflation in 2003 to exceed the National Bank of Hungary's inflation target by 5 percentage points. $^{48}$

A third problem with an exchange rate target is that it can induce the wrong policy response when a country if faced with real shocks such as a terms of trade shock. Two graphic examples occurred in New Zealand and Chile in the late 1990s. By early 1997, the Reserve Bank institutionalized this focus by adopting as its primary indicator of monetary policy a Monetary Conditions Index (MCI) similar to that developed by the Bank of Canada. The idea behind the MCI, which is a weighted average of the exchange rate and a short-term interest rate, is that both interest rates and exchange rates on average have offsetting impacts on inflation. When the exchange rate falls, this usually leads to higher inflation in the future, and so interest rates need to rise to offset the upward pressure on inflation. However, the offsetting effects of interest rates and exchange rates on inflation depend on the nature of the shocks to the exchange rates. If the exchange rate depreciation comes from portfolio considerations, then it does lead to higher inflation and needs to be offset by an

48 Analysts have interpreted this as an evidence that the NBH is determined to maintain the currency band even at the cost of temporary higher inflation. See IMF (2002). 
interest rate rise. However, if the reason for the exchange rate depreciation is a real shock such as a negative terms-of-trade shock which decreases the demand for a country's exports, then the situation is entirely different. The negative terms of trade shock reduces aggregate demand and is thus likely to be deflationary. The correct interest rate response is then a decline in interest rates, not a rise as the MCI suggests.

With the negative terms of trade shock in 1997, the adoption of the MCI in 1997 led to exactly the wrong monetary policy response to East Asian crisis. With depreciation setting in after the crisis began in July 1997 after the devaluation of the Thai baht, the MCI began a sharp decline, indicating that the Reserve Bank needed to raise interest rates, which it did by over 200 basis points. The result was very tight monetary policy, with the overnight cash rate exceeding $9 \%$ by June of 1998 . Because the depreciation was due to a substantial, negative terms of trade shock which decreased aggregate demand, the tightening of monetary policy, not surprisingly, lead to a severe recession and an undershoot of the inflation target range with actual deflation occurring in $1999 .^{49}$ The Reserve Bank of New Zealand did eventually realize its mistake and reversed course, sharply lowering interest rates beginning in July 1998 after the economy had entered a recession, but by then it was too late.

Chile's inflation targeting regime also included a focus on limiting exchange rate fluctuations by having an exchange rate band with a crawling peg which was (loosely) tied to lagged domestic inflation. This focus on the exchange rate induced a serious policy mistake in 1998 because the central bank was afraid it might lose credibility in the face of the financial turmoil if it allowed the exchange rate to depreciate after what had taken place in financial markets after the East Asian crisis and the Russian meltdown. Thus instead of easing monetary policy in the face of the negative terms of trade shock, the central bank raised interest rates sharply and even narrowed its exchange rate band. The result was that the inflation target was undershot and the economy entered a recession for the first time in the 1990s. With this outcome, the central bank came under strong criticism for the first time since it had adopted its inflation targeting regime in 1990, weakening support for the independence of the central bank and its inflation targeting regime. During 1999, the central bank did reverse course, easing monetary policy by lowering interest rates and allowing the peso to decline.

The contrast of the experience of New Zealand and Chile during this period with that of Australia, another small open economy with an inflation targeting regime, is striking. Prior to adoption of their inflation targeting regime in 1994, the Reserve Bank of Australia had adopted a policy of allowing the exchange rate to fluctuate without interference, particularly if the source of the exchange rate change was a real shock, like a terms of trade shock. Thus when faced with the devaluation in Thailand in July 1997, the Reserve Bank recognized that it would face a substantial

49 The terms of trade shock, however, was not the only negative shock the New Zealand economy faced during that period. Its farm sector experienced a severe drought which also hurt the economy. Thus, a mistake in monetary policy was not the only source of the recession. Bad luck played a role too. See Drew and Orr (1999) and Brash (2000). 
negative terms of trade shock because of the large component of its foreign trade conducted with the Asian region and that it should not fight the depreciation of the Australian dollar that would inevitably result. $^{50}$ Thus in contrast to New Zealand, it immediately lowered the overnight cash rate by 50 basis points to $5 \%$ and kept it near at this level until the end of 1998, when it was lowered again by another 25 basis points.

A more subtle approach to exchange rate intervention can avoid some of the problems of an exchange rate peg. Intervention in the foreign exchange market to depreciate the domestic currency could be an important element of non-conventional monetary policy of raising price level expectations, without announcing a precise exchange rate target. Instead the central bank and the government could emphasize that exchange-rate interventions, along with other measures, are being conducted as a method of pursuing expansionary monetary policy and to achieve a higher price level and a stronger economy. These interventions would then be unsterilized in order to make clear that their primary purpose is to produce expansionary monetary policy that raises the price level and is not focused on a target level of the exchange rate. ${ }^{51}$ The communication strategy would also be helped by having the government and the central bank emphasize that the exchange rate interventions to escape from the deflation trap would eventually help encourage purchases of foreign goods and would eventually be highly beneficial for the country's trading partners.

At the zero interest rate, the difference between sterilized and unsterilized intervention, namely the interest rate channel, disappear. However, even at the zero interest rate, we believe that the unsterilized intervention is more stimulative than sterilized intervention, primarily due to a signiling effect. Unsterilized intervention provides one more instrument to achieve quantitative easing, and conducting unsterilized intervention will make the central bank look more willing to commit to continuing ZIRP in the future.

7.2.4 Open market purchase of private, real assets

50 See MacFarlane (1999) and Stevens (1999).

51 Under the Hayami regime, the Bank of Japan resisted the suggestion that interventions be unsterilized. Since interventions are decided and conducted by the Ministry of Finance, making interventions unsterilized was seen as a dictation of monetary policy by the Ministry of Finance-a violation to independence. In 2003, under the Fukui regime, interventions became more frequent on the part of the Ministry of Finance, and quantitative easing was accelerated on the part of the Bank of Japan. From January 2003 to December 2003, about 15 trillion yen of interventions increased the yen in the market in exchange for an increase in inventory of foreign currencies, while the ceiling of the Bank of Japan current account target was raised by 12 trillion yen. Deputy Governor Iwata in his reply to a question in the press conference on October 1, 2003 acknowledged that these two actions, ex post, were equivalent to unsterilized interventions, although "it must be coincident." This is much more nuanced statement than a typical reaction during the Hayami regime. (press interview, October 1, 2003, available in Japanese text through the Bank of Japan homepage http://www.boj.or.jp/press/03/kk0310a.htm, translated by one of the authors of this paper.) 
An even more radical step for monetary authorities would be to purchase real assets such as stocks, corporate bonds or real estate. Purchase of these assets would raise their prices directly and would lead to expansion in aggregate demand though a number of channels of monetary transmission (Mishkin, 1996). Purchase of real assets would also directly help restore balance sheets in the economy and help get the financial system working again, which we have seen is crucial to recovery if the country finds itself in a situation like Japan's.

However, central bank purchase of these assets is not without problems. Government purchase of private assets can be highly politicized. Which assets should the central bank buy? Different elements in the private sector would lobby for purchase of the assets that would make them profits. Some of this problem could be mitigated by the central bank buying broad based bundles of assets or market indices so that specific private firms do not benefit over others. However, there still is the question of how much real estate should be bought versus stocks, or how much corporate bonds versus equities. Decisions on what to buy would have important distributional consequences, which would put the central bank under intense political pressure. Not only might this result in distortionary decisions, but it could politicize the central bank and interfere with the independence that this institution has worked so hard to get.

Another problem with central-bank purchase of private assets is that it involves the government in ownership of the private sector. The trend in recent years has been toward privatization because it is believed that the private sector has better incentives to produce efficiently than does the government sector. Having substantial purchases of private assets by the central bank, which after all is a government entity, goes against this trend. Maybe the problems of central-bank ownership of private assets can be minimized by announcing that the central bank will have no involvement in running of the companies or real estate that it has taken a position in, but political pressures may make this hard to do.

If central-bank purchases of private, real assets are sizeable, there could be adverse consequences both for the central bank and the economy. However, if nothing else worked, then this more radical step might be necessary as a way of stimulating the economy and achieving a higher price level.

Our discussion here has indicated that none of the non-conventional monetary policy strategies are without their problems. There is thus an argument for what might be crudely described as a "kitchen sink" or "throw it against the wall and see if it sticks approach". Because it would not be clear how well the different approaches would work, some or all of them could be tried to see which ones work best. One concern might be that the uncertainty about the impact of the different approaches might make it harder to be sure of what the outcome of using them might be. One outcome would be paralysis and then not to try any of them. 
There are two responses to these concerns. The first is that having a clear cut price level/inflation target to pin down expectations can make it highly likely that less conventional tools of monetary policy can achieve the goal of price stability and that inflation would not spin out of control. In recent years we have seen major successes in the ability of monetary policy to control inflation in many industrialized countries. We would argue that this is not because central banks have become so much more knowledgeable about the transmission mechanisms of monetary policy. What has changed in recent years is that central banks in industrialized countries have been able to put much stronger nominal anchors in place. The result is greatly improved performance on both the inflation and output fronts. One method has been to adopt inflation targets, as in the New Zealand, Canada, the United Kingdom, Sweden and Australia, and to some extent in the European Monetary Union. ${ }^{52}$ Alternatively, a strong nominal anchor can be put into place without a formal inflation target through direct communication with the public about the commitment to price stability and actions that are consistent with it. This is the strategy pursued by the Federal Reserve, which has as strong a nominal anchor as inflation-targeting, central banks although it is embodied in an individual, Alan Greenspan (Mishkin, 2000). Adopting a price level target and then possibly moving to an inflation target would go a long way to ensuring an escape from the deflation trap, while making it highly unlikely that inflation would spin out of control thereafter.

\section{Concluding Remarks}

This paper reviews the experience of Japanese monetary policy over the last two decades with an emphasis on the experience of deflation from the mid-1990s. The cost of deflation is quite high, and prolonged deflation makes it more difficult to get out of it. A key element in escaping deflation is the management of expectations and we have seen that price level and inflation targeting attempt to achieve exactly this. Also because the credibility of price level and inflation targets require actions, non-conventional policy measures become relevant when prices are declining and the zero lower bound on interest rates mean that the overnight interest rate can no longer be used as the instrument of monetary policy.

We are quite critical of the conduct of the BOJ monetary policy from 1998 to 2003 . The Bank of Japan's rhetoric was not helpful in fighting deflation, and the interest rate hike in August 2000 amid deflation was a serious mistake. Although rhetoric has improved under the new Governor Fukui since 2003, more is needed to get out of deflation completely. We surveyed the literature on cost of deflation, the optimal level of inflation, and relative merits of price level vs. inflation targets. A key to curing deflation is management of expectations, and here a history dependent policy involving

52 The European Central Bank does not officially call their monetary policy strategy "inflation targeting" but it is pretty close: there is a strong commitment to price stability and an explicit inflation goal of "less than but close to $2 \%$ " has been announced. 
a price-level target can help. However, because actions speak louder than words, management of expectations also involves non-conventional monetary policies. Admittedly, there is uncertainty about how these policies would work, but a combination of them can help the Japanese economy escape its deflationary trap. 


\section{References}

Ahearne, Alan, Joseph Gagnon, Jane Haltmaier, Steve Kamin, and others, "Preventing Deflation: Lessons from Japan's Experiences in the 1990s," Board of Governors, International Finance Discussion Paper No. 729, June 2002.

Akerlof, George, Dickens, William, and George Perry, 1996. "The Macroeconomics of Low Inflation," Brookings Papers on Economic Activity 1: 1-59.

Atkeson, Andrew and Patrick J. Kehoe (2004). "Deflation and Depression: Is There and Empirical Link?" NBER Working Paper No. 10268 (January).

Auerbach, Alan J. and Maurice Obstfeld (2003), "The Case for Open Market Purchases in a Liquidity Trap,” Working Paper, University of California, Berkeley

Battini, N. and T. Yates, 1999. "Hybrid Inflation and Price Level Targeting," mimeo., Bank of England.

Berg, Claes and Lars Jonung (1999), "Pioneering Price Level Targeting: The Swedish Experience 1931-1937,” Journal of Monetary Economics 43, pp. 525-551.

Bernanke, Ben.S. (1983). "Nonmonetary Effects of the Financial Crisis in the Propagation of the Great Depression," American Economic Review 73: 257-76.

Bernanke, Ben. S. (2000), “Japanese Monetary Policy: A Case of Self-Induced Paralysis?”, in Ryoichi Mikitani and Adam S. Posen, eds., Japan's Financial Crisis and its Parallels to U.S. Experience, Institute for International Economics, 2000.

Bernanke, Ben S. (2002), “Deflation: Making Sure “It” Doesn't Happen Here,” remarks before the National Economists' Club, November 21 ${ }^{\text {st }}, 2002$.

Bernanke, Ben and Mark Gertler (1999). "Monetary Policy and Asset Price Volatility," Federal Reserve Bank of Kansas City, Economic Review, $4^{\text {th }}$ Quarter, 17-51. [Also reprinted in Federal Reserve Bank of Kansa City, New Challenges for Monetary Policy, 77-128.]

Bernanke, Ben S., Laubach, Thomas, Mishkin, Frederic S. and Adam S. Posen, 1999. Inflation Targeting: 
Lessons from the International Experience, Princeton University Press: Princeton.

Bernanke, Ben S. and Frederic S. Mishkin, 1997. "Inflation Targeting: A New Framework for Monetary Policy?" Journal of Economic Perspectives 11, 2: 97-116.

Black, Richard; Macklem and David Rose, 1998. "On Policy Rules for Price Stability," Price Stability, Inflation Targets and Monetary Policy, Proceedings of a Conference held by Bank of Canada, May 1997, Ottawa, Canada: 411-61.

Blinder, Alan S. (1998) Central Banking in Theory and Practice MIT Press, 1998.

Brash, Donald T. 2000. "Inflation Targeting in New Zealand, 1988-2000," Speech to the Trans-Tasman Business Cycle, Melbourne, February 9.

Boskin, Michael J., Dulberger, Ellen R., Gordon, Robert J., Griliches, Zvi and Dale W. Jorgenson, 1996.

"Toward a More Accurate Measure of the Cost of Living," Final Report to the Senate Finance Committee, December.

Card, D. and D. Hyslop (1997) “Does Inflation 'Grease the Wheels of the Labor Market'?” in Reducing Inflation: Motivation and Strategy, edited by C.D. Romer and H.D. Romer pp. 71-114, Chicago: University of Chicago Press

Cargill, Thomas; Michael Hutchison, and Takatoshi Ito (1997), The Political Economy of Japanese Monetary Policy, Cambridge, MA: MIT Press.

Cargill, Thomas; Michael Hutchison, and Takatoshi Ito (2000). Financial Policy and Central Banking in Japan, Cambridge, MA: MIT Press.

Cecchetti, Stephen G.; Hans Genberg; John Lipsky; and Sushil Wadhwani, (2000), Asset Prices and Central Bank Policy, Geneva Reports on the World Economy no. 2, Geneva: International Center for Monetary and Banking Studies.

Clarida, Richard, J.; Jordi Gali, and Mark Gertler (1998). "Monetary Rules in Practice: Some International Evidence,” European Economic Review, vol. 42: 1033-1067.

Clarida, Richard, Jordi Gali and Mark Gertler (1999), “The Science of Monetary Policy: A New-Keynesian 
Perspective,” Journal of Economic Literature 37, pp. 1661-1707

Clouse, James; Dale Henderson; Athanasios Orphanides; David Small; and Peter Tinsley, (2000).

"Monetary Policy When the Nominal Short-term Interest Rate is Zero", Board of Governors of the Federal Reserve System, International Finance Discussion Papers, number 729.

Crawford, A. and A. Harrison (2000) "Testing for Downward Rigidity in Nominal Wage Rates," in Price Stability, Inflation Targets and Monetary Policy pp. 179-218 Proceedings of a conference held by the Bank of Canada, May 1997 Ottawa: Bank of Canada.

Dittmar, Robert and William Gavin (2000), "What Do New-Keynesian Phillips Curves Imply for Price-Level Targeting?" Federal Reserve Bank of St. Louis Review, vol. 82, no. 2, March-April: 21-30.

Ditmar, Robert, Gavin, William T. and Finn E. Kydland. 1999, "The Inflation-Output Variability Tradeoff and Price Level Targets," Review, Federal Reserve Bank of St. Louis: 23-31.

Dittmar, Robert, Gavin, William T. and Finn E. Kydland. 2000, "What Do New-Keynesian Phillips Curves Imply for Price-Level Targeting," Review, Federal Reserve Bank of St. Louis: 21-30.

Drew, Aaron and Adrian Orr, 1999. "The Reserve Bank's Role in the Recent Business Cycle: Actions and Evolution," Reserve Bank of New Zealand Bulletin, 62, No. 1.

Eggertsson, Gauti (2003), "Fighting Deflation at Zero Nominal Interest Rates: Committing to Being Irresponsible,” IMF Working Paper no. 03/64 March 1, 2003

Eggertsson, Gauti B. and Michael Woodford (2003), "Optimal Monetary Policy in a Liquidity Trap," NBER Working Paper 9968.

Erceg, Christopher and Andrew Levin (2001) “Imperfect Credibility and Inflation Persistence,” Federal Reserve Board Working Paper, 2001

Estrella, Arturo and Jeffrey Fuhrer (1998), "Dynamic Inconsistencies: Counterfactual Implications of a Class of Rational Expectations Models,” Federal Reserve Bank of Boston Working Paper: 98/05, July 1998

Fares Jean and Thomas Lemieux (2000) "Downward Nominal-Wage Rigidity: A critical Assessment and Some New Evidence from Canada," in Price Stability and the Long-Run Target for Monetary Policy 
proceedings of a seminar held by the Bank of Canada, June 2000 Ottawa: Bank of Canada

Feldstein, Martin, 1997. "Capital Income Taxes and the Benefits of Price Stability," NBER Working Paper No. 6200, September.

Fischer, Irving, 1933. "The Debt-Deflation Theory of Great Depressions", Econometrica, Vol. 1: 337-57.

Fischer, Stanley. 1994. "Modern Central Banking," in Forest Capie, Charles Goodhart, Stanley Fischer and Norbert Schnadt, The Future of Central Banking, Cambridge University Press, Cambridge, U.K.: 262-308.

Friedman, Benjamin (2003), "Discussion of 'Inflation Targeting: A Critical View," presented at the Federal Reserve Ban of St. Louis Annual Conference, "Inflation Targeting: Prospects and Problems," October 16-17.

Fuhrer, Jeffrey C. and Brian Madigan, (1997) “Towards a Compact, Empirically-Verified Rational Expectations Model for Monetary Policy Analysis," Carnegie-Rochester Conference Series on Public Policy, 47, 197-230.

Fujiki, Hiroshi; Kunio Okina; and Shigenori Shiratsuka, (2001). "Monetary Policy under Zero Interest Rate: Viewpoints of Central Bank Economists," Bank of Japan, Monetary and Economic Studies, February: 89-130.

Fuhrer, Jeffrey C. (1997), "The (Un)Importance of Forward-Looking Behavior in Price Specifications," Journal of Money, Credit, and Banking, vol. 29, no. 3, August 1997, pp. 338-50

Fukui, Toshihiko, (2003). "Challenges for Monetary Policy in Japan," Speech at the Spring Meeting of the Japan Society of Monetary Economics, June 1.

Gaspar, Vitor and Frank Smets, 2000. "Price Level Stability: Some Issues," mimeo., European Central Bank.

Goodfriend, Marvin (2001). "Financial Stability, Deflation, and Monetary Policy,” in Bank of Japan, Monetary and Economic Studies, vol. 19, no. S-1, Special Edition, February: 143-176.

Greenspan, Alan (2002) "Issues for Monetary Policy," remarks by Chairman Alan Greenspan before the Economic Club of New York, New York City 
Greenspan, Alan (2004) "Risk and Uncertainty in Monetary Policy," remarks by Chairman Alan Greenspan at the meeting of the American Economic Association, San Diego, California January 3, 2004

Groshen, Erica L. and Schweitzer, Mark E. 1996. "The Effects of Inflation on Wage Adjustments in Firm-Level Data: Grease or Sand?" Federal Reserve Bank of New York Staff Reports, No. 9.

Groshen, Erica L. and Schweitzer, Mark E. 1999. "Identifying Inflation's Grease and Sand Effects in the Labor Market," in Martin Feldstein, ed., The Costs and Benefits of Price Stability University of Chicago Press, Chicago: 273-308

Harrigan, James and Kenneth Kuttner (2004). "Lost Decade in Translation: Has the US Learned from Japan's Post-bubble Mistakes?” presented at the Solution Conference, Tokyo, June.

Hoshi, Takeo and Anil Kashyap, 2004. "Solutions to the Japanese Banking Crisis: What Might Work and What Definitely Will Fail,” University of Tokyo and Columbia University, the Solutions conference, June.

Hunter, William C.; George G. Kaufman, and Michael Pomerleano, (2003). Asset Price Bubbles: The Implications for Monetary, Regulatory, and International Policies, MIT Press.

Ito, Takatoshi (1992). The Japanese Economy, Cambridge, MA: MIT Press.

Ito, Takatoshi (1999). “A Target for the Bank of Japan,” Financial Times, October 19.

Ito, Takatoshi (2000). "Nihon ni Okeru Inflation Targeting Seisaku” (in Japanese, transl. "Inflation Targeting Policy in Japan”) in Fukao, Mitsuhiro and Hiroshi Yoshikawa (ed.), Zero Kinri to Nihon Keizai (in Japanese, transl. Zero Interest Rate and the Japanese Economy), Tokyo: Nihon Keizai Shinbun Pub.

Ito, Takatoshi (2001). Inflation Targeting (written in Japanese), Tokyo: Nihon Keizai Shinbun Pub.

Ito, Takatoshi (2003). "Looking Forward on Monetary and Supervision Policies to Protect against Bubbles" in W. C. Hunter, G. G. Kaufman, and M. Pomerleano, Asset Price Bubbles: The Implications for Monetary, Regulatory, and International Policies, MIT Press: 547-552.

Ito, Takatoshi (2004). "Inflation Targeting and Japan: Why has the Bank of Japan not Adopted Inflation Targeting?" forthcoming in Reserve Bank of Australia, The Future of Inflation Targeting. 
Ito, Takatoshi and Kimie Harada, 2000. "Japan Premium and Stock Prices: Two Mirrors of Japanese Banking Crises” NBER working paper no 7997, November.

Ito, Takatoshi and Tomoko Hayashi, 2004. Inflation Targeting in Asia, Hong Kong Institute for Monetary Research, Occasional Paper, No. 1, March.

Ito, Takatoshi and Tokuo Iwaisako, 1996. "Explaining Asset Bubbles in Japan," The Bank of Japan, Monetary and Economic Studies, vol. 14, July: 143-193.

Iwata, Kazumasa, 2002. "Deflation Spiral Hassei no Kanousei" (in Japanese, trans. "Possibility of Having a Deflation Spiral," in R. Komiya, Kinyu Seisaku rongi no Soten, (in Japanese, trans. Issues in the Monetary Policy Debate), Tokyo: Nihon Keizai Shinbun, pub.: 121-156.

Iwata, Kikuo, 2001. Deflation no Keizaigaku, (in Japanese, trans. Economics of Deflation) Tokyo: Toyo Keizai Shinpo, Pub.

Iwata, Kikuo, 2001. Deflaiton no Keizaigaku (in Japanese, trans. Economics of Deflation), Tokyo: Toyo Keizai Shinpo, Pub.

Iwata, Kikuo, 2002. "Yosou Keisei ni Hataraki kakeru Kinyu Seisakuo," (in Japanese, trans. "Recommding Monetary Policy to Affect Inflation Expectation," in R. Komiya, Kinyu Seisaku rongi no Soten, (in Japanese, trans. Issues in the Monetary Policy Debate), Tokyo: Nihon Keizai Shinbun, pub.: 391-418.

Jinushi, Toshiki; Yoshihiro Kuroki, and Ryuzo Miyao (2000). "Monetary Policy inJapan Since the Late 19870s: Delayed Policy Actions and Some Explanations,” in Mikitani and Posen (eds.), Japan's Financial Crisis and Its Parallels to U.S. Experience. Washington D.C.: Institute for International Economics, chapter 6.

Jonas, Jiri and Frederic S. Mishkin, (2004), "Inflation Targeting in Transition Countries: Experience and Prospects," (with Jiri Jonas) in Michael Woodford, ed., Inflation Targeting (University of Chicago Press: Chicago, forthcoming.)

Kamada, Koichiro, (2004). "Real-Time Estimation of the Output Gap in Japan and its Usefulness for Inflation Forecasting and Policy Making” Bank of Japan, mimeo, April 16. http://www.e.u-tokyo.ac.jp/cirje/research/workshops/macro/macropaper04/kamada.pdf 
King, Mervyn, 1996. "How Should Central Banks Reduce Inflation?- Conceptual Issues," in Achieving Price Stability, Federal Reserve Bank of Kansas City, Kansas City, MO: 53-91.

King, Mervyn, 1999, "Challenges for Monetary Policy: New and Old," in New Challenges for Monetary Policy, Federal Reserve Bank of Kansas City, Kansas City, Missouri:11-57.

Krugman, Paul (1998), “It's Baack! Japan's Slump and the Return of the Liquidity Trap,” Brookings Papers on Economic Activity 1998, vol. 2, pp. 137-187

Kuroda, Sachiko and Isamu Yamamoto, (2003a). "Are Japanese Nominal Wages Downwardly Rigid? (Part I): Examinations of Nominal Wage Change Distributions,” Bank of Japan, Monetary and Economic Studies, vol 21, no.2. August: 1-30.

Kuroda, Sachiko and Isamu Yamamoto, (2003b). “Are Japanese Nominal Wages Downwardly Rigid? (Part

II): Examinations Using a Friction Model,” Bank of Japan, Monetary and Economic Studies, vol 21, no.2. August: 31-68.

Kuroda, Sachiko and Isamu Yamamoto, (2003c). “The Impact of Downward Nominal Wage Rigidity on the Unemployment Rate: Quantitative Evidence from Japan,” Bank of Japan, Monetary and Economic Studies, vol 21, no.4, December: 57-85.

Kuttner, Kennth N. and Adam S. Posen (2004). "The Difficulty of Discerning What's Too Tight: Taylor Rules and Japanese Monetary Policy."

Lebow, David E., Brian Saks, and Beth A. Wilson (1999), "Downward Nominal Wage Rigidity: Evidence from the Employment Cost Index,” FEDS Working Paper 1999-31, Board of Governors of the Federal Reserve System, July.

Lebow, David E., David J. Stockton and W. L. Wascher (1995) "Inflation, Nominal Wage Rigidity and the Efficiency of the Labor Market," Board of Governors of the Federal Reserve Working Paper 94-45, October 1995

Macfarlane, Ian J. 1999. "Statement to Parliamentary Committee," in Reserve Bank of Australia Bulletin, January: $16-20$. 
McCallum, Bennett T. (1999), "Issues in the Design of Monetary Policy Rules," in John B. Taylor and Michael Woodford, eds. Handbook of Macroeconomics, North Holland, Amsterdam, forthcoming.

McCallum, Bennett (2000a), "Theoretical Analysis Regarding a Zero Lower Bound on Nominal Interest Rates," Journal of Money, Credit and Banking, vol. 32, no. 2, pp. 879-904.

McCallum, Bennett T. (2000b). “Alternative Monetary Policy Rules: A comparison with Historical Settings for the United States, and United Kingdom, and Japan," Federal Reserve Bank of Richmond, Economic Quarterly, vol. 86, Winter: 49-79.

McCallum, Bennett (2002), "Inflation Targeting and the Liquidity Trap,” in N. Loayza and R. Soto, eds. Inflation Targeting: Design, Performance, Challenges, Central Bank of Chile

McCallum, Bennett (2003), “Japanese Monetary Policy 1991-2001,” Federal Reserve Bank of Richmond Economic Quarterly 89

McLean, D. and H. Pioro, (2000). "Price Level Targeting -- The Role of Credibility," paper presented at the Bank of Canada Conference, Price Stability and the Long-Run Target for Monetary Policy, June 8-9, 2000.

McKinnon, Ronald I. And Kenichi Ohno, (1997). Resolving Economic Conflict between the United States and Japan, MIT Press.

Meltzer, Allan H. 1995. "Monetary, Credit and Other Transmission Mechanism Processes: A Monetarist Perspective," Journal of Economic Perspectives, 9: 49-72.

Meltzer, Allan, 1998. “Time to Print Money,” Financial Times, July 17.

Meltzer, Allan, 2001. "Monetary Transmission at Low Inflation: Some Clues from Japan in the 1990s," Bank of Japan, Monetary and Economic Studies, vol. 19, no.S-1: 13-34.

Meulendyke, Ann-Marie, US Monetary Policy and Financial Markets New York, Federal Reserve Bank of New York, 1998

Mishkin, Frederic S. 1978. "The Household Balance-Sheet and the Great Depression," Journal of Economic History 38, December: 918-937. 
Mishkin, Frederic S. 1991. "Asymmetric Information and Financial Crises: A Historical Perspective," in R. Glenn Hubbard, ed., Financial Markets and Financial Crises, University of Chicago Press: Chicago: 69-108.

Mishkin, Frederic S., 1996. "The Channels of Monetary Transmission: Lessons for Monetary Policy," Banque De France Bulletin Digest No. 27: 33-44.

Mishkin, Frederic S., 1997. "The Causes and Propagation of Financial Instability: Lessons for Policymakers," Maintaining Financial Stability in a Global Economy, Federal Reserve Bank of Kansas City, Kansas City, MO.: 55-96.

Mishkin, Frederic S., 1998. "Promoting Japanese Recovery," in Kenichi Ishigaki and Hiroyuki Hino, eds., Towards the Restoration of Sound Banking Systems in Japan -- the Global Implications (Kobe University Press and International Monetary Fund: Kobe 1998). 130-161.

Mishkin, Frederic S. 1999a. "International Experiences with Different Monetary Policy Regimes," Journal of Monetary Economics, Vol. 43, \#3: 579-606.

Mishkin, Frederic S., 1999b. "Central Banking in a Democratic Society: Implications for Transition Countries," in Mario Blejer and Marko Skreb, eds. Central Banking, Monetary Policy and the Implications for Transition Economies, Kluwer Academic Publishers, Boston: 31-53.

Mishkin, Frederic S. (2000) "What Should Central Banks Do?" Federal Reserve Bank of St. Louis Review, vol. 82, \#6 (November/December 2000): 1-13.

Mishkin, Frederic S. (2001), "The Transmission Mechanism and the Role of Asset Prices in Monetary Policy," in Aspects of the Transmission Mechanism of Monetary Policy, Focus on Austria 3-4/2001. (Osterreichische Nationalbank: Vienna): 58-71.

Mishkin, Frederic S. (2004a) "Why the Fed Should Adopt Inflation Targeting," International Finance 7:1 (2004), forthcoming.

Mishkin, Frederic S. (2004b). “Can Central Bank Transparency Go Too Far?” forthcoming in Reserve Bank of Australia, The Future of Inflation Targeting.

Mishkin, Frederic S. and Adam S. Posen (1997), "Inflation Targeting: Lessons from Four Countries," 
Federal Reserve Bank of New York, Economic Policy Review, vol. 3, \#3 (August): 9-110.

Mishkin, Frederic S. and Eugene N. White (2003) "U.S. Stock Market Crashes and Their Aftermath: Implications for Monetary Policy," in William B. Hunter, George G. Kaufman and Michael Pormerleano, eds., Asset Price Bubbles: The Implications for Monetary, Regulatory and International Policies (MIT Press, Cambridge Mass.: 53-79.

Morgan, J.P. (2003), Emerging Europe, Middle East \& Africa Weekly, January 31.

Moulton, Brett R. 1996. "Bias in the Consumer Price Index: What is the Evidence," Journal of Economic Perspectives 10 )4): 159-77.

Okina, Kunio (1999a). "Monetary Policy under Zero Inflation: A Response to Criticisms and Questions Regarding Monetary Policy,” Bank of Japan, Monetary and Economic Studies, vol. 17: 157-182.

Okina, Kunio (1999b). "Rejoinder to Comments Made by Professors McKinnon and Meltzer,” Bank of Japan Monetary and Economic Studies, vol. 17: Institute for Monetary and Economic Studies, Bank of Japan, 192-197.

Oda, Nobuyuki and Kunio Okina (2001). "Further Monetary Easing Policies under the non-Negativity Constraints of Nominal Interest Rates: Summary of the Discussion Based on Japan's Experience,” Bank of Japan, Monetary and Economic Studies, vol. 19, no. S-1: 323-370.

Okina, Kunio and Shigenori Shiratsuka (2002). “Asset Price Bubbles, Price Stability, and Monetary Policy: Japan's experience,” Bank of Japan, Monetary and Economic Studies, October: 35-76.

Okina, Kunio and Shigenori Shiratsuka (2004). "Policy Commitment and Expectation Formation: Japan's Experience under Zero Interest Rates,” North American Journal of Economics and Finance, vol. 15: 75-100.

Okina, Kunio; Masaaki Shirakawa, and Shigenori Shiratsuka (2001), "The Asset Price Bubble and Monetary Policy: Japan's Experience in the Late 1980s and the Lessons" Background Paper for the conference: Monetary and Economic Studies (special edition) February: 395-450.

Orphanides, Athanasios and Volker Wieland (1998), "Price Stability and Monetary Policy Effectiveness When Nominal Interest Rates are Bounded by Zero," FEDS Working Paper 1998-35, Board of Governors 
of the Federal Reserve System, August.

Orphanides, Athanasios and Volker Wieland (2000), "Efficient Monetary Policy Design near Price Stability," Journal of Japanese and International Economies 14, pp. 327-356

Posen, Adam S. (1998), Restoring Japan's Economic Growth, Institute for International Economics, Washington, DC

Poole, William, 1999. "Is Inflation Too Low," Review, Federal Reserve Bank of St. Louis, 81,4: 3-10.

Reifschneider, David and John Williams (2000) "Three Lessons for Monetary Policy in a Low Inflation Era," Journal of Money, Credit and Banking (November 2000): 936-966.

Richards, Anthony and Tim Robinson (2003), Asset Prices and Monetary Policy, Reserve Bank of Australia.

Romer, Christine, 1992. "What Ended the Great Depression?" Journal of Economic History, December 1992, 52, \#4, 757-784.

Sarno, Lucio and Mark P. Taylor (2001). "Official Intervention in the Foreign Exchange Market: Is It Effective and, If So, How Does It Work?" Journal of Economic Literature, vol. XXXIX, September: 839-868.

Shiratsuka, Shigenori (1999). "Measurement Errors and Quality-Adjustment Methodology: Lessons from the Japanese CPI," Federal Reserve Bank of Chicago, Economic Perspectives, $2^{\text {nd }}$ Quarter: 2-13.

Stevens, Glenn R. 1999. "Six Years of Inflation Targeting," Reserve Bank of Australia Bulletin, May: 46-61.

Svensson, Lars and Michael Woodford, (1999). “

Taylor, John, editor, 1999. Monetary Policy Rules (University of Chicago Press for the NBER: Chicago 1999): $405-430$.

Shapiro, Matthew D. and David W. Wilcox, 1996. "Mismeasurement in the Consumer Price Index, An Evaluation," in Ben S. Bernanke and Julio J. Rotemberg, eds. NBER Macroeconomics Annual, MIT Press, 
Cambridge, Mass.: 83-154.

Smets, Frank, 2000. "What Horizon for Price Stability," European Central Bank Working Paper 24.

Summers, Lawrence H. 1991. "How Should Long-Term Monetary Policy Be Determined?" Journal of Money Credit and Banking, 23: 625-631,

Svensson, Lars, E.O, 1999. "Price-Level Targeting Versus Inflation Targeting: A Free Lunch," Journal of Money, Credit and Banking, 31: 277-95.

Svensson, L.O. (2001), "The Zero Bound in an Open Economy: A Foolproof Way of Escaping from a Liquidity Trap,” Monetary and Economic Studies, vol. 19, no. S-1, February: 277-312

Svensson, L.O. (2003), "Escaping from a Liquidity Trap and Deflation: the Foolproof Way and Others," NBER Working Paper 10195

Svensson, L.O. and Michael Woodford (2003), "Optimal Policy with Partial Information in a

Forward-Looking Model: Certainty-Equivalence Redux,” NBER Working Paper 9430

Taylor, John, editor, 1999. Monetary Policy Rules, University of Chicago Press for the NBER, Chicago.

Taylor, John B. (2001). "Low Inflation, Deflation, and Policies for Future Price Stability,” Bank of Japan, Monetary and Economic Studies (special edition) February: 35-51.

Ueda, Kazuo (1999), "Remarks" Fed Conference on "Monetary Policy in a Low-Inflation Environment," in Woodstock, Vermont on October 20. (www.boj.or.jp/en/press/04/press_f.htm)

Ueda, Kazuo (2000). "The Transmission Mechanism of Monetary Policy Near Zero Interest Rates: The Japanese Experience 1998-2000”, Speech given at a Conference Sponsored by the National Bureau of Economic Research, European Institute of Japanese Studies, Tokyo University Center for International Research on the Japanese Economy, and the Center for Economic Policy Research, held at Swedish Embassy in Tokyo on September 22, 2000] http://www.boj.or.jp/en/press/04/press_f.htm

Vestin, David, 2000. "Price Level Targeting Versus Inflation Targeting in a Forward Looking Model." mimeo., IIES, Stockholm University, May. 
Williams, J.C., 1999. "Simple Rules for Monetary Policy," Finance and Economics Discussion Series, Board of Governors of the Federal Reserve System.

Woodford, Michael (1999), “Optimal Monetary Policy Inertia,” NBER Working Paper no. 7261.

Woodford, Michael (2000), "Pitfalls of Forward-Looking Monetary Policy," American Economic Review vol. 90, no. 2, pp.100-104.

Woodford, Michael (2003), Interest and Prices: Foundations of a Theory of Monetary Policy, Princeton: Princeton University Press, 2003

Yamaguchi, Yutaka (1999). "Monetary Policy and Structural Policy: A Japanese Perspective", Deputy Governor of the Bank of Japan, before Colloque Moné taire International at Banque de France, October 8-9, 1999. (http://www.boj.or.jp/en/press/04/press_f.htm). 
Figure 1: Land Prices and Stock Prices, 1970-2003

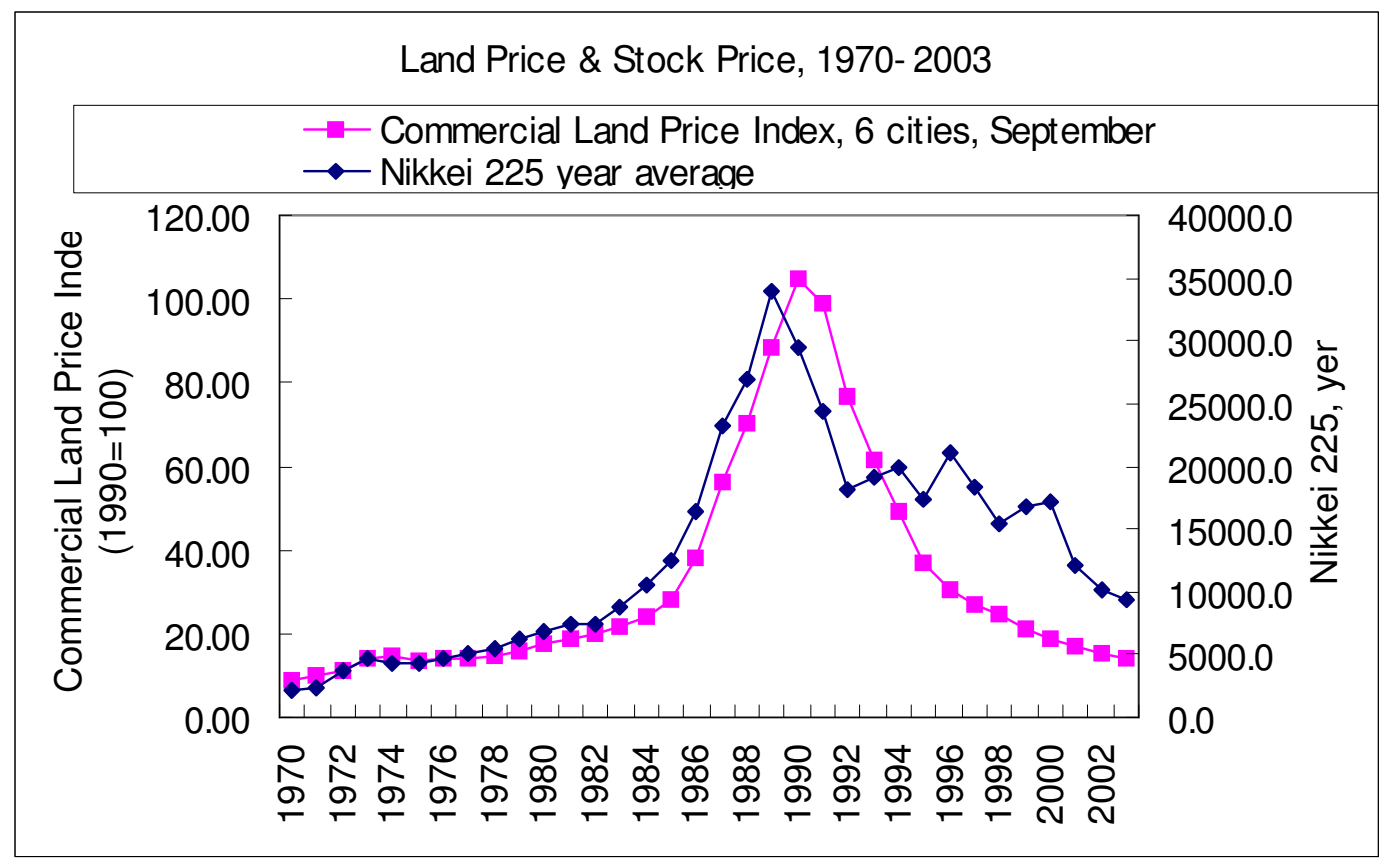


Figure 2: CPI Inflation excluding fresh food and consumption tax, 1985-2002

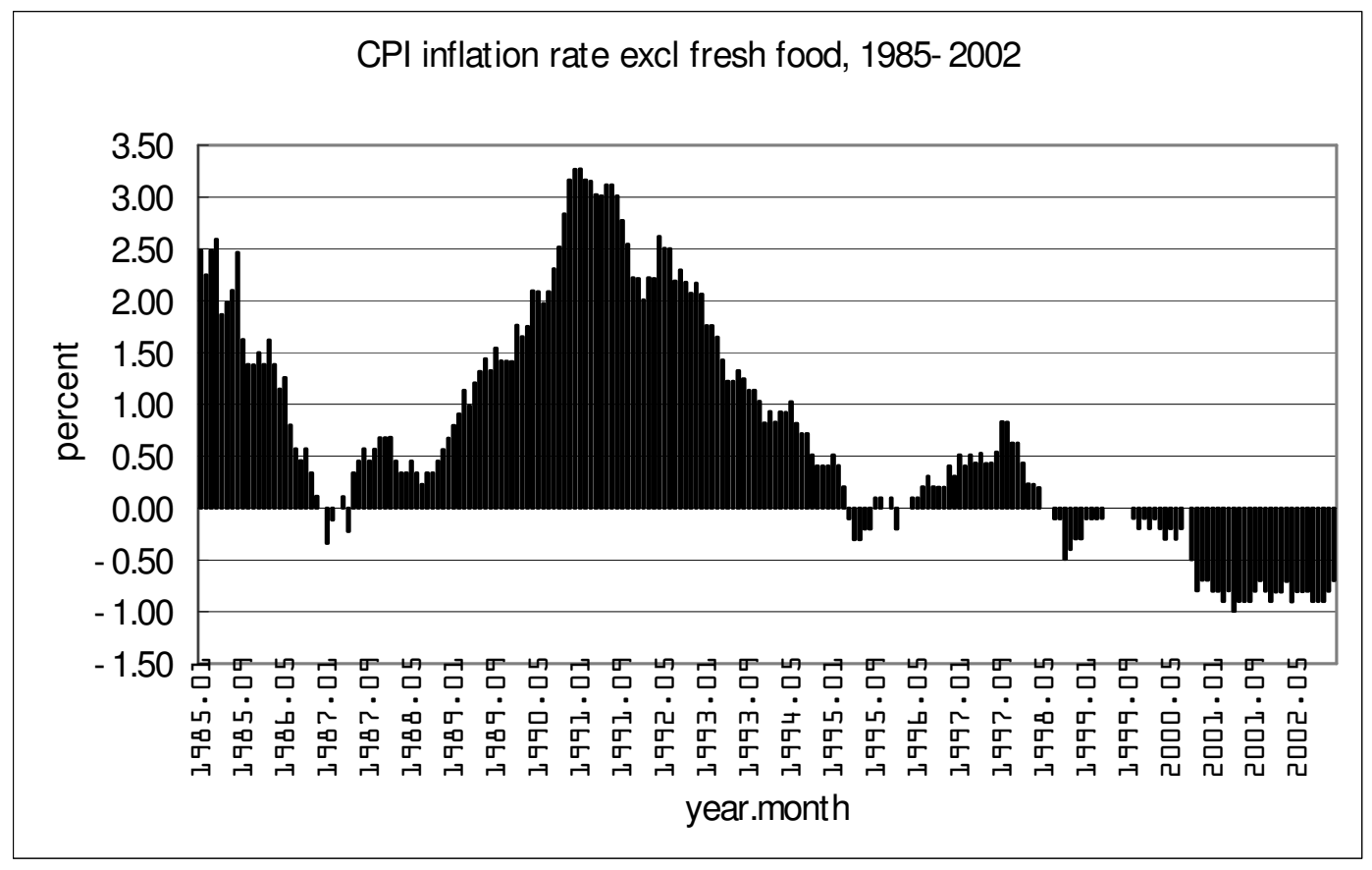


Figure 3 Quantitative easing and Interest rate cut

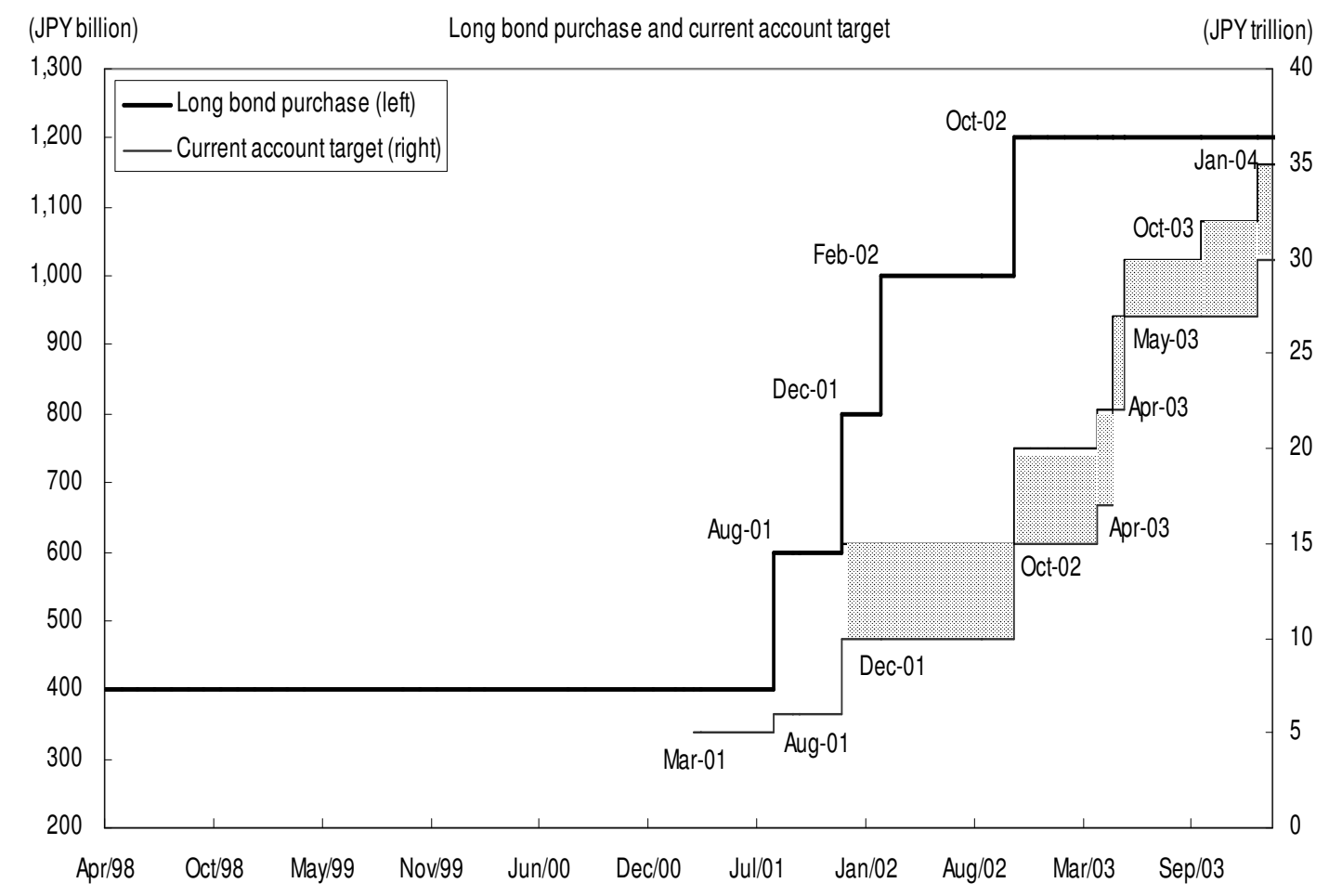

(\%)

Official discount rate and call rate

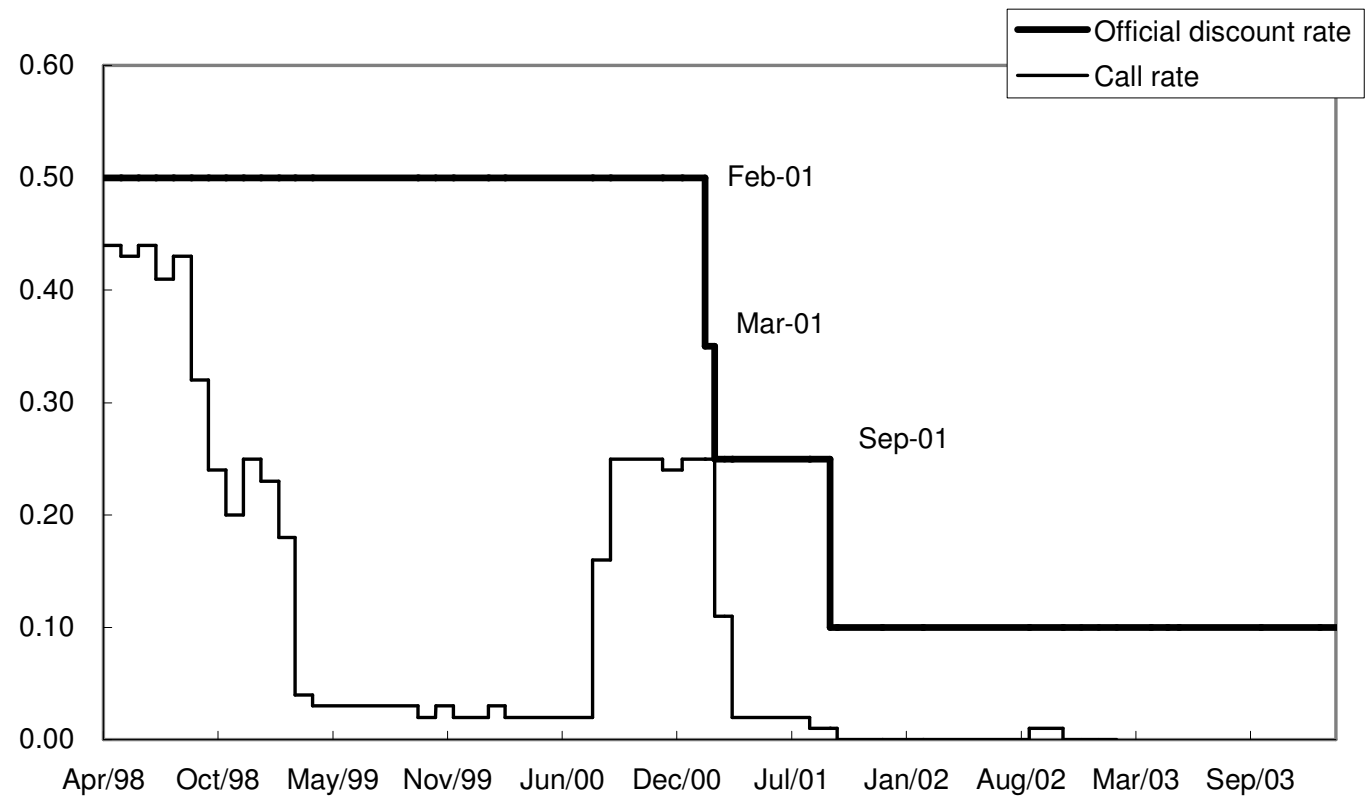


Figure 4 GDP Gap

FIgure 1: GDP gap (fixed lambda)

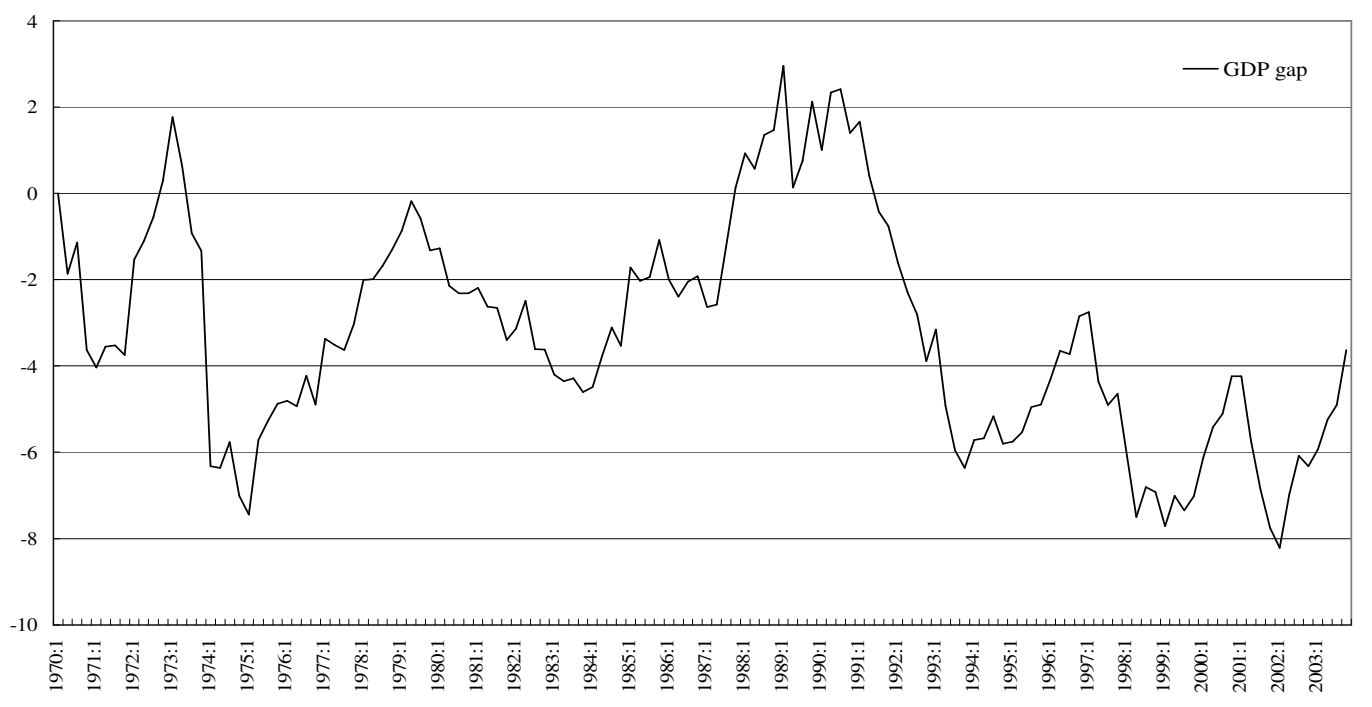


Figure 5

Backward-looking model

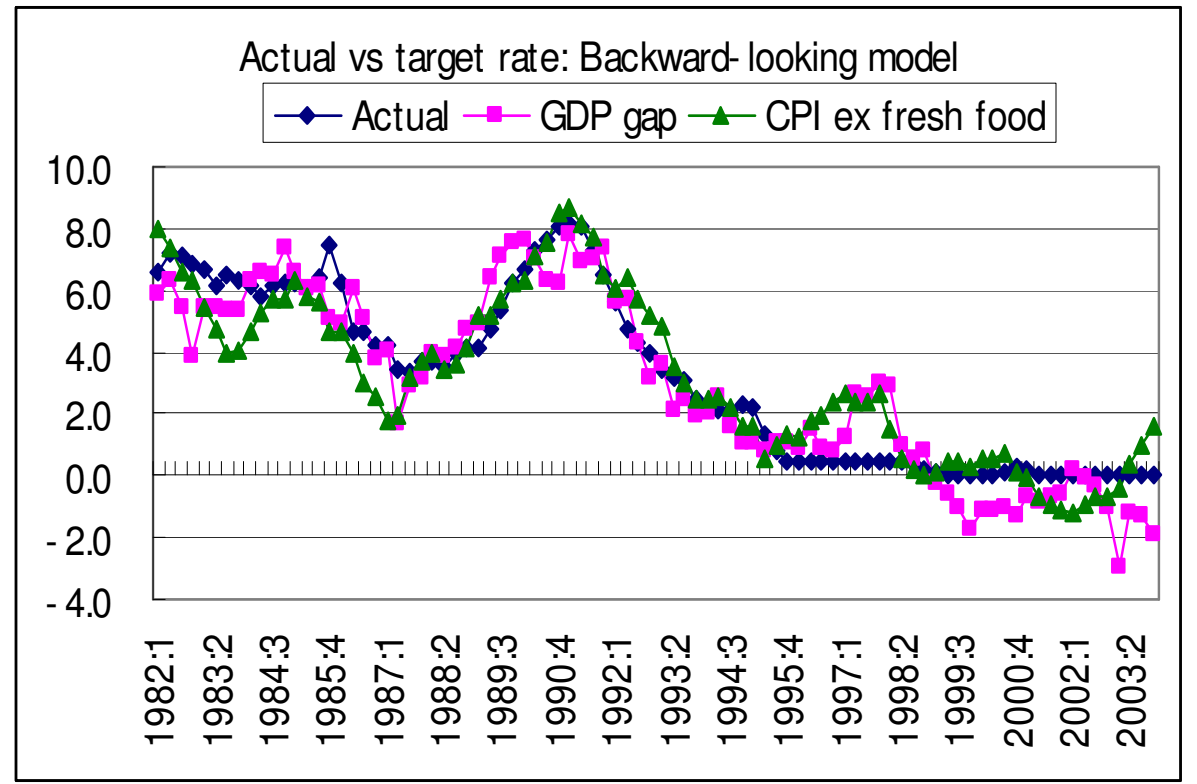

Forward-looking model

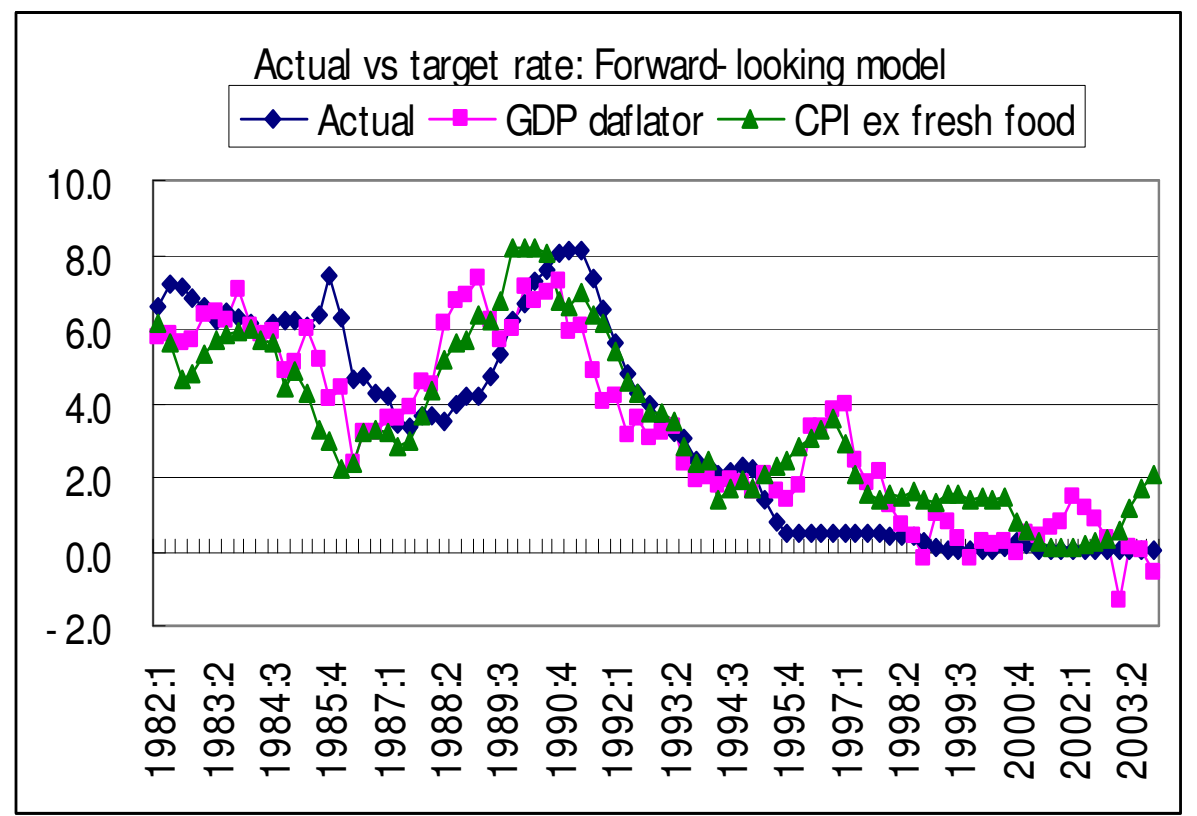


Figure 6.

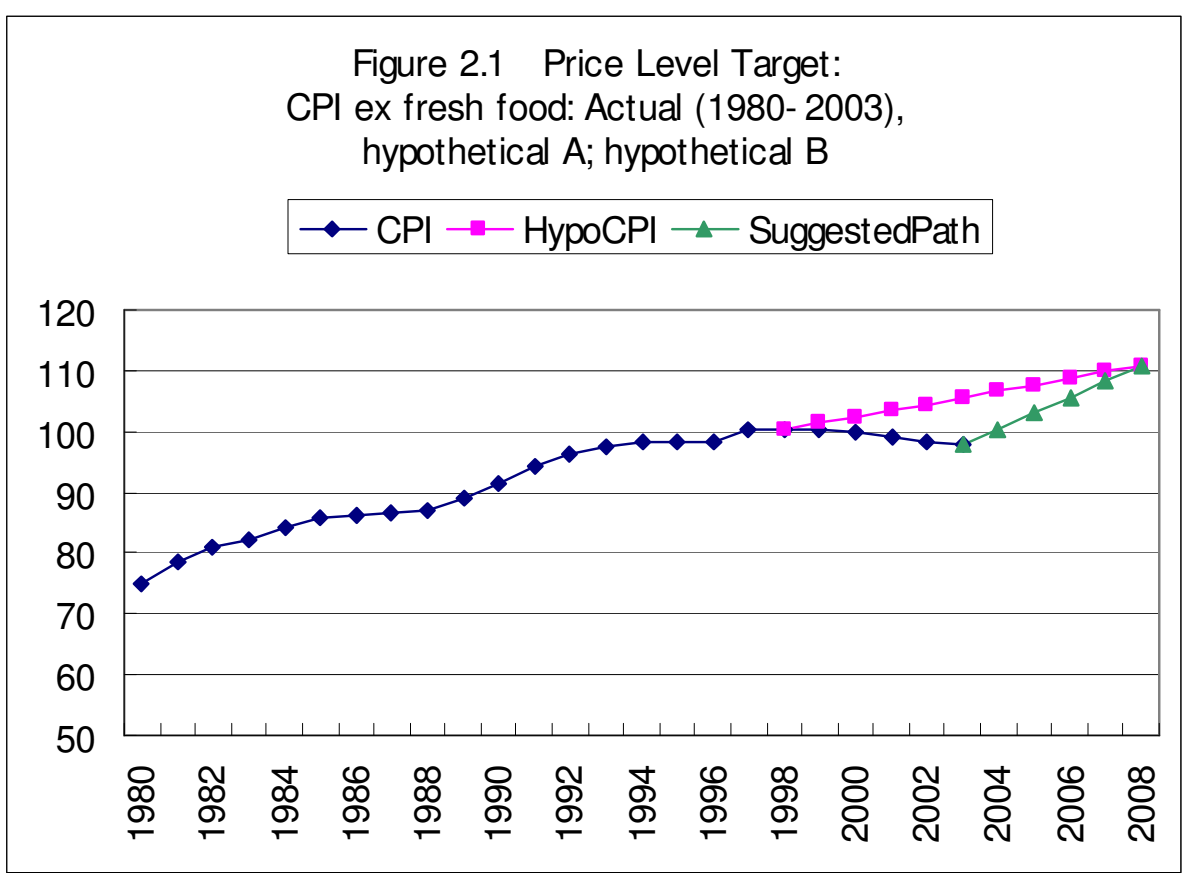


Figure 7

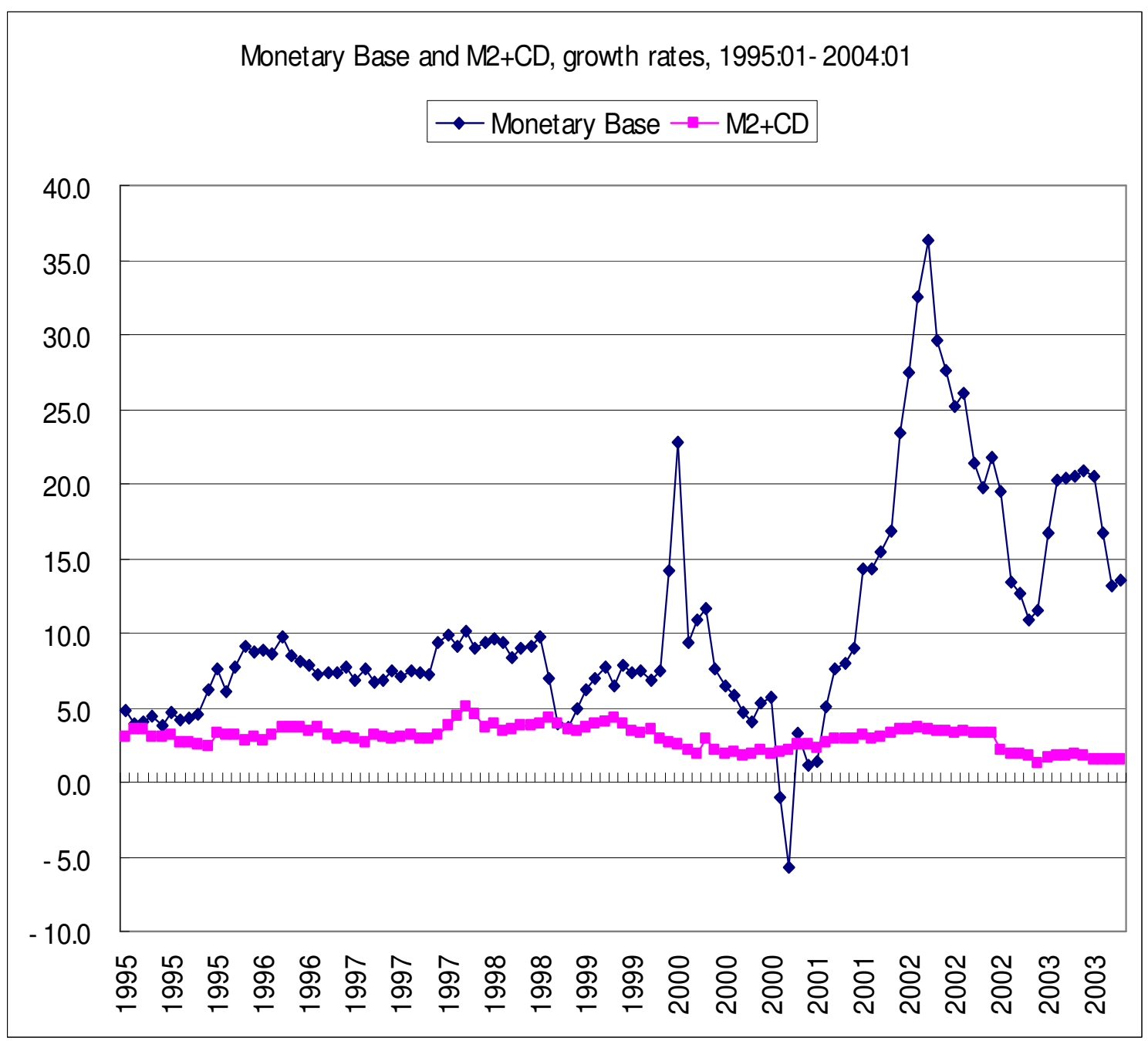


Table 1: Taylor Rule model in Japan

Backward Looking model

\begin{tabular}{|l|l|l|}
\hline & $(1)$ & $(2)$ \\
\hline & Inflation rate gap & Inflation rate gap \\
\hline & GDP deflator & CPI ex fresh food \\
\hline & $1982: 1-1994: 4$ & $1982: 1-1994: 4$ \\
\hline Constant & $\begin{array}{l}5.799 * * * \\
(0.183)\end{array}$ & $\begin{array}{l}6.201 * * * \\
(0.134)\end{array}$ \\
\hline GDP deflator or & $1.468 * * *$ & $1.752^{* * *}$ \\
CPI ex fresh food & $(0.090)$ & $(0.133)$ \\
\hline GDP gap & $0.214 * * *$ & $0.307 * * *$ \\
& $(0.053)$ & $(0.040)$ \\
\hline R squared & 0.799 & 0.791 \\
\hline DW & 0.662 & 0.323 \\
\hline
\end{tabular}

Forward Looking model

\begin{tabular}{|l|l|l|}
\hline & $(1)$ & $(2)$ \\
\hline & Inflation rate gap & Inflation rate gap \\
\hline & GDP deflator & CPI ex fresh food \\
\hline & $1982: 1-1994: 4$ & $1982: 1-1994: 4$ \\
\hline Constant & $\begin{array}{l}5.629 * * * \\
(0.323)\end{array}$ & $\begin{array}{l}6.067 * * * \\
(0.266)\end{array}$ \\
\hline GDP deflator or & $1.233^{* * *}$ & $1.706^{* * *}$ \\
CPI ex fresh food & $(0.110)$ & $(0.276)$ \\
\hline GDP gap & 0.114 & 0.151 \\
& $(0.081)$ & $(0.097)$ \\
\hline R squared & 0.619 & 0.594 \\
\hline DW & 0.253 & 0.162 \\
\hline
\end{tabular}

Notes:

Standard errors in brackes are heteroskadastic-consistent

$*$ **, and $* * *$ mean that the null hypotheses are rejected at $10 \%, 5 \%$, and $1 \%$, respectively. 